\title{
The phenology of an urban street flora: a transect study
}

\author{
C.D. Preston \\ Cambridge, England
}

\section{Corresponding author: cdpr@ceh.ac.uk}

This pdf constitutes the Version of Record published on $26^{\text {th }}$ February 2020

\begin{abstract}
Vascular plants in flower along a fixed $3.8 \mathrm{~km}$ route in eight streets in a primarily residential area of urban Cambridge, U.K., were recorded at monthly intervals between January 2016 and December 2019. There was a consistent annual pattern over the four years; the number of flowering species was greatest in June or July but there were still appreciable numbers of species flowering when totals were at their lowest in February or March. Five annuals (Capsella bursa-pastoris, Euphorbia peplus, Poa annua, Senecio vulgaris, Stellaria media) and one perennial (Parietaria judaica) were very frequent and flowered from January to December. Perennial species showed greater variation through the year than annual species. In most months the number of flowering British native species exceeded the combined number of archaeophytes and neophytes, but the native total peaked earlier in the summer and then declined more rapidly than that of the introductions. The transect method appeared to be effective in identifying the main annual phenological trends and also revealed the effects of extreme weather on the patterns in some seasons.
\end{abstract}

Keywords: annual; archaeophyte; Cambridge; native; neophyte; perennial; weather; weedkiller.

\section{Introduction}

In January 2016 I took part in the BSBI New Year Plant Hunt, in which participants were invited to spend up to three hours in the field listing the vascular plants they could find in flower (Marsh, 2016). I recorded those growing in the streets around my home in Cambridge (v.c.29), U.K. Although the results were interesting, it was difficult to put them into context in the absence of any systematic information on the flowering times of the species at other times of year. I therefore decided to repeat the exercise at monthly intervals. This paper reports the results of four years' recording, from January 2016 to December 2019, as a contribution to our knowledge of the phenology of plants in urban habitats.

\section{The study area}

The study area (Fig. 1) lies on the north side of the River Cam (TL4459, 4559) in 'transpontine' Cambridge, north of the historic city centre and at an altitude of $c .15$ $\mathrm{m}$. The south-western part includes the medieval churches of St Peter and St Giles, and the site of Cambridge Castle (now demolished). It also abuts onto the northern edge of Magdalene College, the most northerly of the historic colleges. Of the streets studied, only Castle Street and Mount Pleasant and its nearby streets were in 
existence by 1688 (Loggan, 1690). The rest of the area was developed as 'New Chesterton' after the parliamentary enclosure of the parish of Chesterton in 1838 (Wright, 1989). As the names Victoria Road and Albert Street indicate, the streets here were laid out and their houses built in the $19^{\text {th }}$ century. Concerns by Magdalene and Trinity Colleges that the area might become a 'low suburb' were largely disregarded and much of the development consisted of terrace housing erected for the less affluent residents of the town. Subsequent changes have included the replacement in recent years of many small commercial premises by housing.

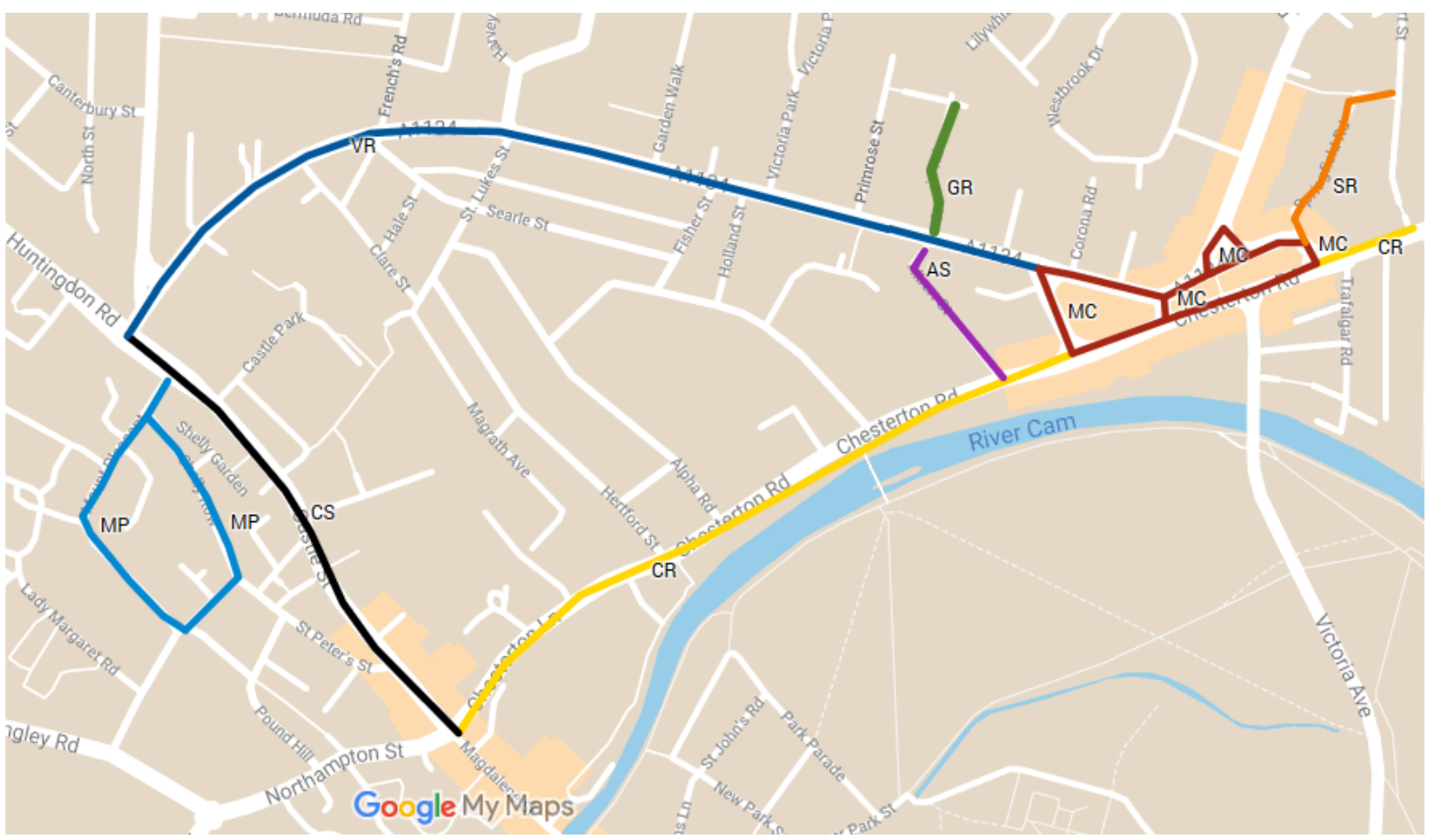

Figure 1. The transect on the north side of the River Cam in Cambridge, with the eight sections differentiated by colour and labelled with the abbreviations used in Table 1. Map data @ 2020 Google.

\section{The transect method}

The method consisted of walking a defined route through a series of streets and recording the plants seen in flower along them. My aim was to record the route in the first four days of the month, following the rules for the New Year Plant Hunt in 2016. I was able to do this on 38 of the 48 occasions on which I recorded the transect. In nine of the remaining ten months, I recorded it within 1-2 days of this four-day span, and only on one occasion (September 2019) did an absence abroad mean that I had to record it 4-7 days before the start of the month. The monthly survey took 2.5-3 hours in the winter but four hours or more in summer, when there were more species to record.

The route taken is shown in Fig. 1. The total length of the streets surveyed is $3.8 \mathrm{~km}$ and the route is divided into eight sections, each section comprising a single street or, in two cases, a group of short streets (Fig. 2). I recorded each section separately (Table 1), and included both sides of the streets on single street lists. The flowering species noted were those growing on the streets themselves, including the pavement and any walls, hedges, grass verges, public flower beds and small car 
parks alongside it. Larger public areas alongside the streets, which include three churchyards, a cemetery and the north bank of the River Cam, were not included in the area studied. In 2016 I listed only the presence of flowering plants; from 2017 onwards, I also noted the habitat(s) in which they grew (Table 2).

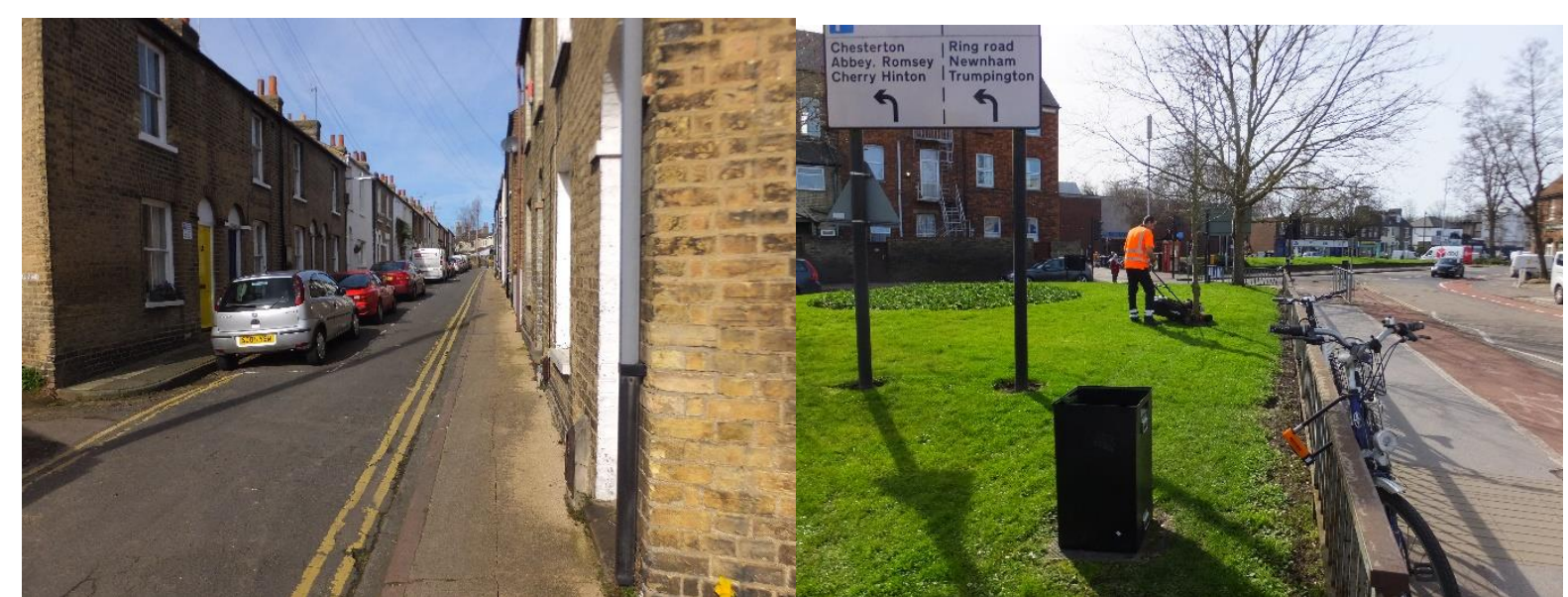

Figure 2. Two contrasting sections of the Cambridge transect, 13 March 2017: (left) Albert Street, a simple street of terrace houses; (right) Mitcham's Corner, a complex roundabout. The circular flower bed behind the street sign on Mitcham's Corner was sown to grass in September 2019.

Table 1. The eight streets, or groups of streets, recorded as sections in the Cambridge transect.

\begin{tabular}{|l|c|l|}
\hline $\begin{array}{l}\text { Street (section } \\
\text { abbreviation) }\end{array}$ & $\begin{array}{c}\text { Length } \\
\text { (km) }\end{array}$ & Description \\
\hline Albert Street (AS) & 0.15 & $\begin{array}{l}\text { Terrace houses without front gardens; small stretches } \\
\text { lined by garden walls at each end (Fig. 2) }\end{array}$ \\
\hline Castle Street (CS) & 0.5 & $\begin{array}{l}\text { Through road lined by pubs, restaurants, two churches, } \\
\text { offices, shops, student accommodation etc. }\end{array}$ \\
\hline $\begin{array}{l}\text { Chesterton Lane/Road } \\
\text { (A1303) (CR) }\end{array}$ & 0.75 & $\begin{array}{l}\text { Through road with street trees, lined by houses, some } \\
\text { with front gardens, church and college walls; excludes } \\
\text { grassy N bank of R Cam }\end{array}$ \\
\hline Green's Road (GR) & 0.1 & $\begin{array}{l}\text { Terrace houses, some with small front gardens; } \\
\text { includes three small gravel-covered car-parking areas } \\
\text { (Figs. 17, 18) }\end{array}$ \\
\hline Mitcham's Corner (MC) & 0.7 & $\begin{array}{l}\text { Roundabout complex ('gyratory system') with a few } \\
\text { street trees, lined by houses, pubs and shops; includes } \\
\text { two islands of grass and flower beds (Figs. 2, 14) }\end{array}$ \\
\hline $\begin{array}{l}\text { Mount Pleasant/Albion } \\
\text { Row/Shelly Row (MP) }\end{array}$ & 0.5 & $\begin{array}{l}\text { Streets lined by college grounds, children's play area } \\
\text { and houses, some with front gardens; includes broad } \\
\text { tree-planted grass verge and bank }\end{array}$ \\
\hline Springfield Road (SR) & 0.2 & $\begin{array}{l}\text { Terrace houses, some with small front gardens; short } \\
\text { length of beech hedge }\end{array}$ \\
\hline $\begin{array}{l}\text { Victoria Road (A1134) } \\
\text { (VR) }\end{array}$ & 0.9 & $\begin{array}{l}\text { Through road, with short stretches grass verge and } \\
\text { some flower beds by road; lined by church, pub, some } \\
\text { shops and houses, some with front gardens }\end{array}$ \\
\hline
\end{tabular}


Table 2. Habitats to which the flowering species were assigned, 2017-2019, with the total number and percentage of records from these habitats. For each section, the records from each habitat are expressed as a percentage of the total number of records in that section. For the abbreviations of the sections, see Table 1.

\begin{tabular}{|l|c|c|c|c|c|c|c|c|c|c|}
\hline Habitat & Records & $\begin{array}{c}\text { All } \\
\mathbf{\%}\end{array}$ & $\begin{array}{c}\text { AS } \\
\mathbf{\%}\end{array}$ & $\begin{array}{c}\text { CR } \\
\mathbf{\%}\end{array}$ & $\begin{array}{c}\text { CS } \\
\mathbf{\%}\end{array}$ & $\begin{array}{c}\text { GR } \\
\mathbf{\%}\end{array}$ & $\begin{array}{c}\text { MC } \\
\mathbf{\%}\end{array}$ & $\begin{array}{c}\text { MP } \\
\mathbf{\%}\end{array}$ & $\begin{array}{c}\text { SR } \\
\%\end{array}$ & $\begin{array}{c}\text { VR } \\
\%\end{array}$ \\
\hline Flower beds & 1348 & 14 & - & 4 & 25 & 15 & 14 & 11 & 5 & 24 \\
\hline Grass & 1752 & 18 & - & 5 & - & 4 & 43 & 42 & 6 & 12 \\
\hline $\begin{array}{l}\text { Gravel-covered } \\
\text { ground }\end{array}$ & 1302 & 13 & 11 & 8 & 13 & 47 & 1 & 4 & 13 & 15 \\
\hline Hedges & 166 & 2 & - & 7 & - & - & - & 1 & 5 & - \\
\hline Pavement & 4313 & 43 & 68 & 51 & 55 & 30 & 32 & 33 & 67 & 45 \\
\hline Soil round tree bases & 374 & 4 & - & 14 & - & 2 & 6 & 1 & - & 1 \\
\hline Walls & 678 & 7 & 21 & 10 & 7 & 3 & 5 & 9 & 3 & 3 \\
\hline
\end{tabular}

Plants which had obviously been deliberately planted, or were strongly suspected of being planted, were not recorded, again following the instructions for the 2016 New Year Plant Hunt. Thus street trees and some flowering bulbs and corms planted on grassy roadsides were disregarded, but 'self-sown' garden escapes were recorded. Viscum album, which became much more frequent on street trees in one section of the transect (Mitcham's Corner) during the period of recording, was not recorded because of its inaccessibility. Epilobium hybrids and a Primula hybrid $(P$. veris $\times$ vulgaris), which were always accompanied by one or both putative parents, were recorded in the field when identifiable but have been excluded from the results presented here. In analysing the results, I have also aggregated the records of some species which in retrospect I suspect that I had recorded inconsistently over the period of the survey, or which I still find difficult to distinguish (Brassica napus/rapa, Calystegia x lucana/silvatica, Erigeron floribundus/sumatrensis, Phleum bertolonii/pratense, Sagina apetala/filicaulis, Symphyotrichum [= Aster] spp.). In the following text these aggregates are treated as species. Otherwise, taxonomy and nomenclature follow Stace (2019). In the following text, the total of species recorded in the entire transect is called the species total, and the sum of the occurrences of species in sections is called the section total.

\section{Number of species recorded}

In all I found 262 species flowering on the streets surveyed. The total number of sections in which the species were seen in flower is shown in Fig. 3. Poa annua was recorded most frequently, in 364 of the 384 ( $8 \times 48)$ sections surveyed, followed by Parietaria judaica (355) and Senecio vulgaris (333). At the other end of the scale, 46 species were recorded just once and at least half of these were present as only a single flowering plant. 


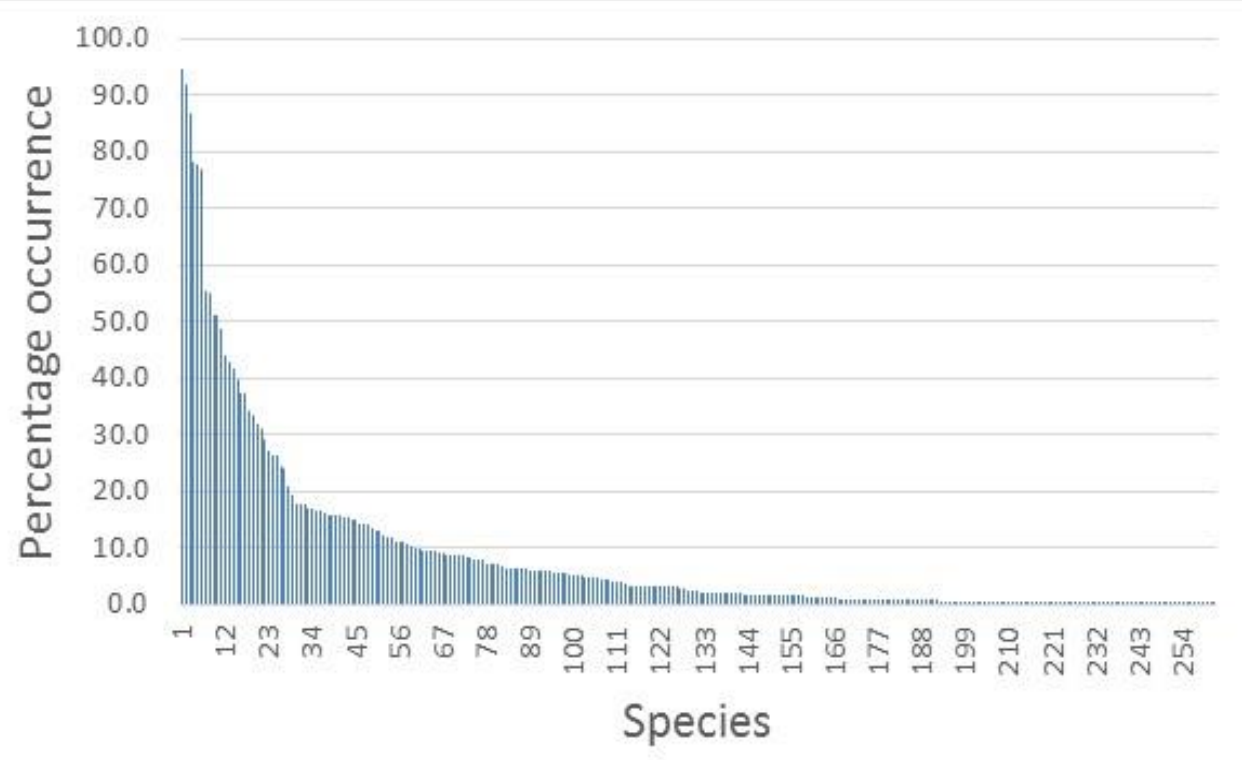

Figure 3. The percentage of the 384 transect sections in which the $\mathbf{2 6 2}$ species were recorded in flower, 2016-2019.

\section{Phenology of the street flora}

The number of species flowering on the transect between 2016 and 2019 is shown in Fig. 4. The four years show a similar pattern, with the lowest number of species flowering at the start of February or (in 2018) March and the greatest number in early June or July. Even in winter the numbers of species which can be found in flower are appreciable, with annual minima of 25-34. The difference between the number of species flowering in winter and summer is thus less than might perhaps be expected, with maximum/minimum values of 3.7-4.7 for species in the four years, and of 3.7-4.1 for the section totals.

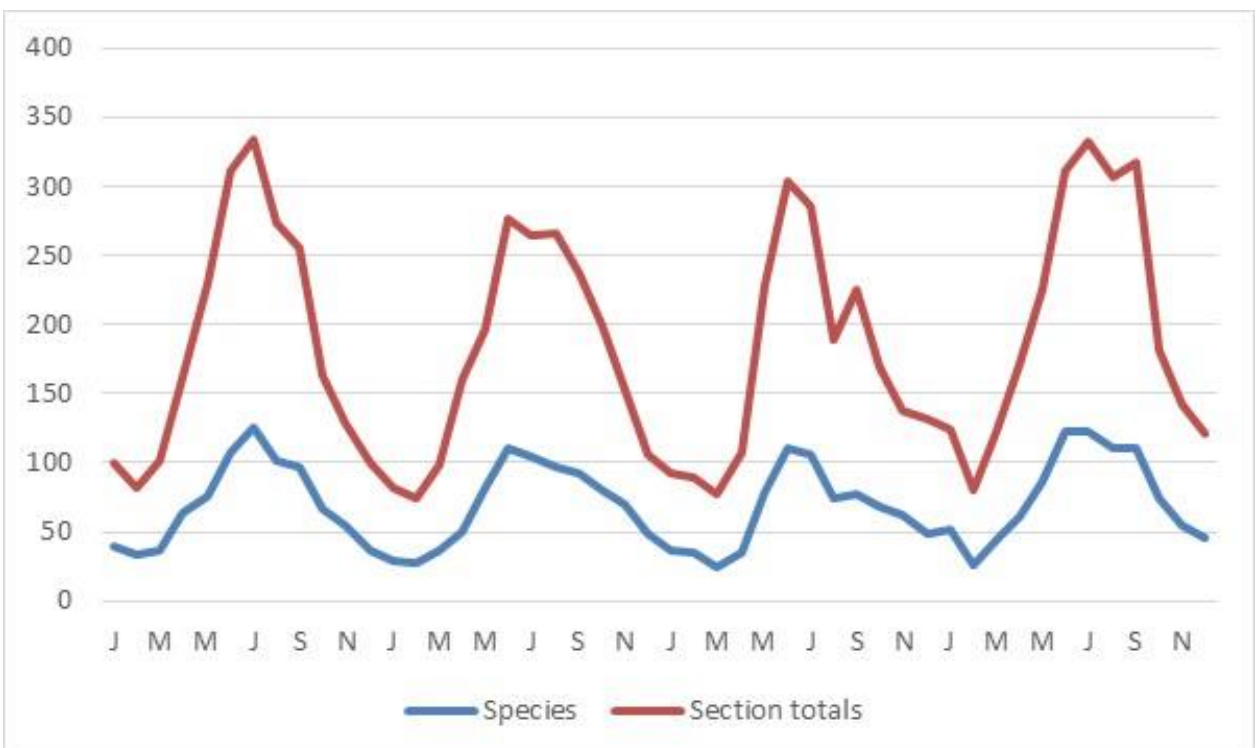

Figure 4. The number of flowering species recorded in the monthly transect, 2016-2019. The blue line gives the monthly species totals and the red line the section totals. 
The phenology of species in the five major habitats along the transect is illustrated in Figs. 5 and 6 . The patterns of flowering are broadly similar for the five habitats. There are some differences in the peak flowering period: the maximum number of species recorded in flower in grass swards was attained in June in all three years, whereas the peak month for flowering was more variable for pavement species, ranging from June (2018) and July (2017) to September (2019).

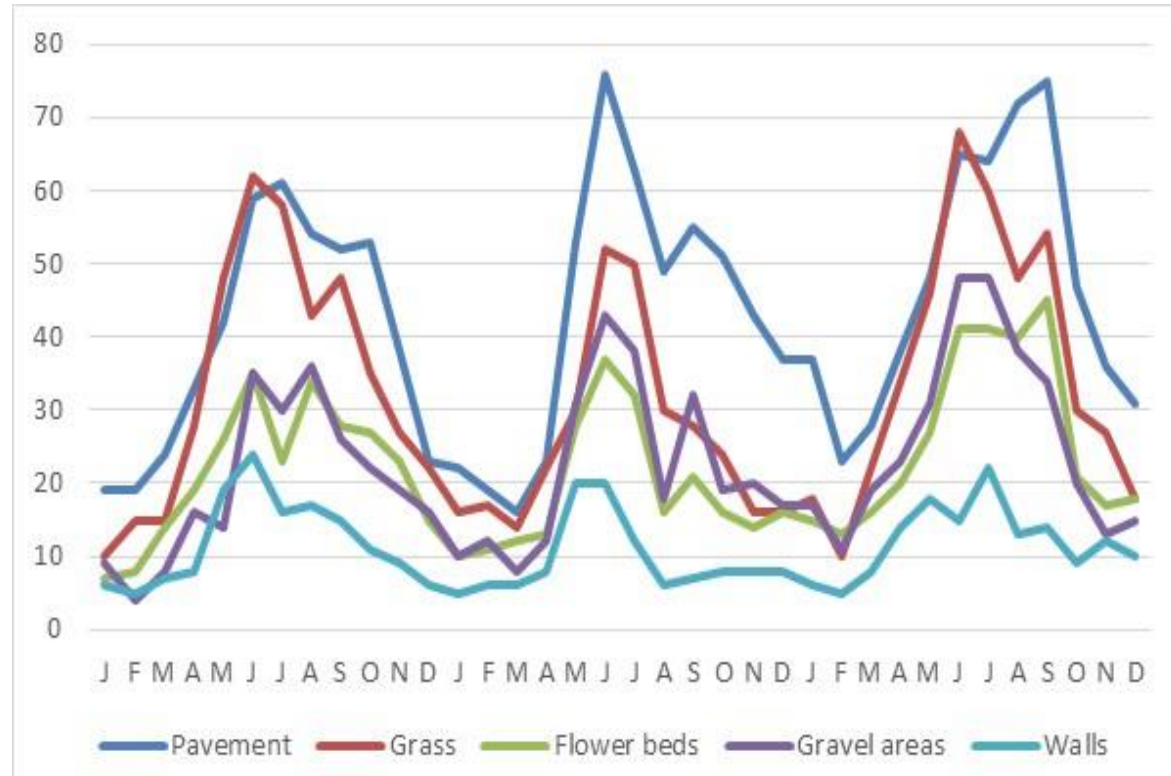

Figure 5. The monthly totals of flowering species recorded in the five major habitats in the transect, 2017-2019.

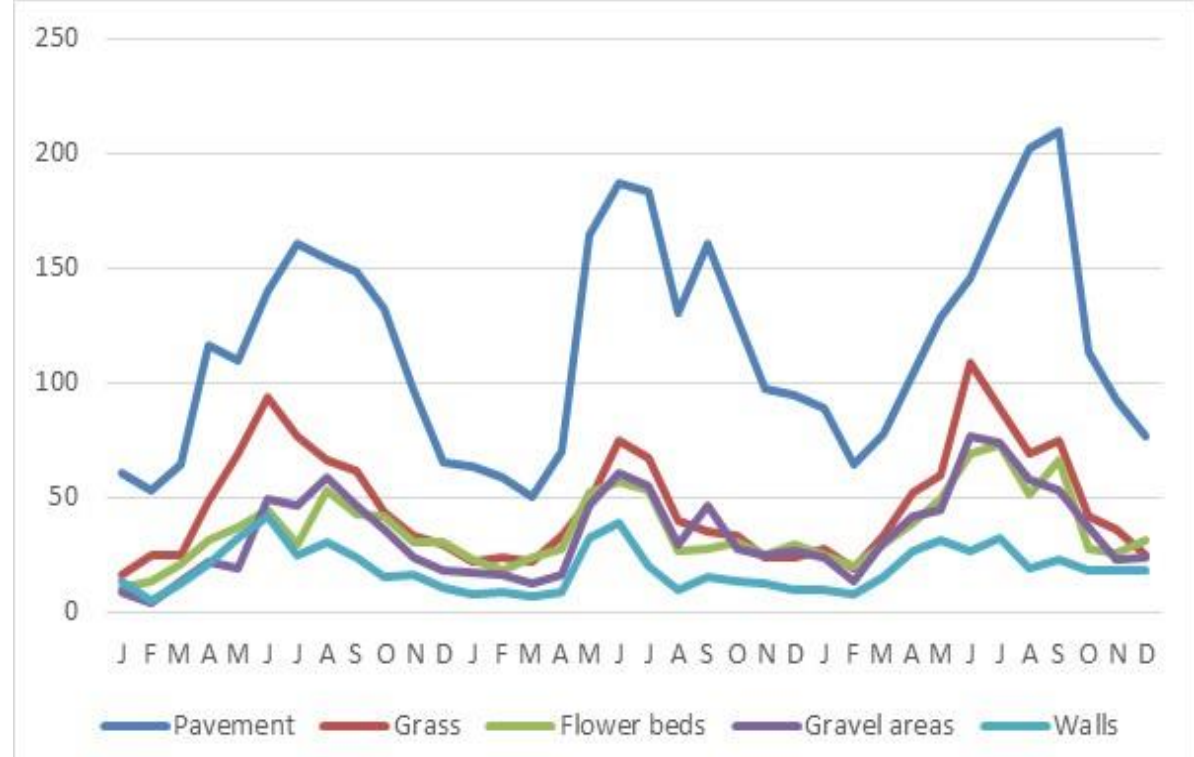

Figure 6. The monthly section totals in the five major habitats in the transect, 2017-2019. 


\section{Phenological patterns analysed by native status and life history}

The separate contributions of annual, biennial and perennial species to the overall phenological patterns are shown in Figs. 7-9. The life history category is the primary type of perennation listed by Hill et al. (2004); the life history categories for rare neophytes not included in this compilation are in most cases taken from Leslie (2019).

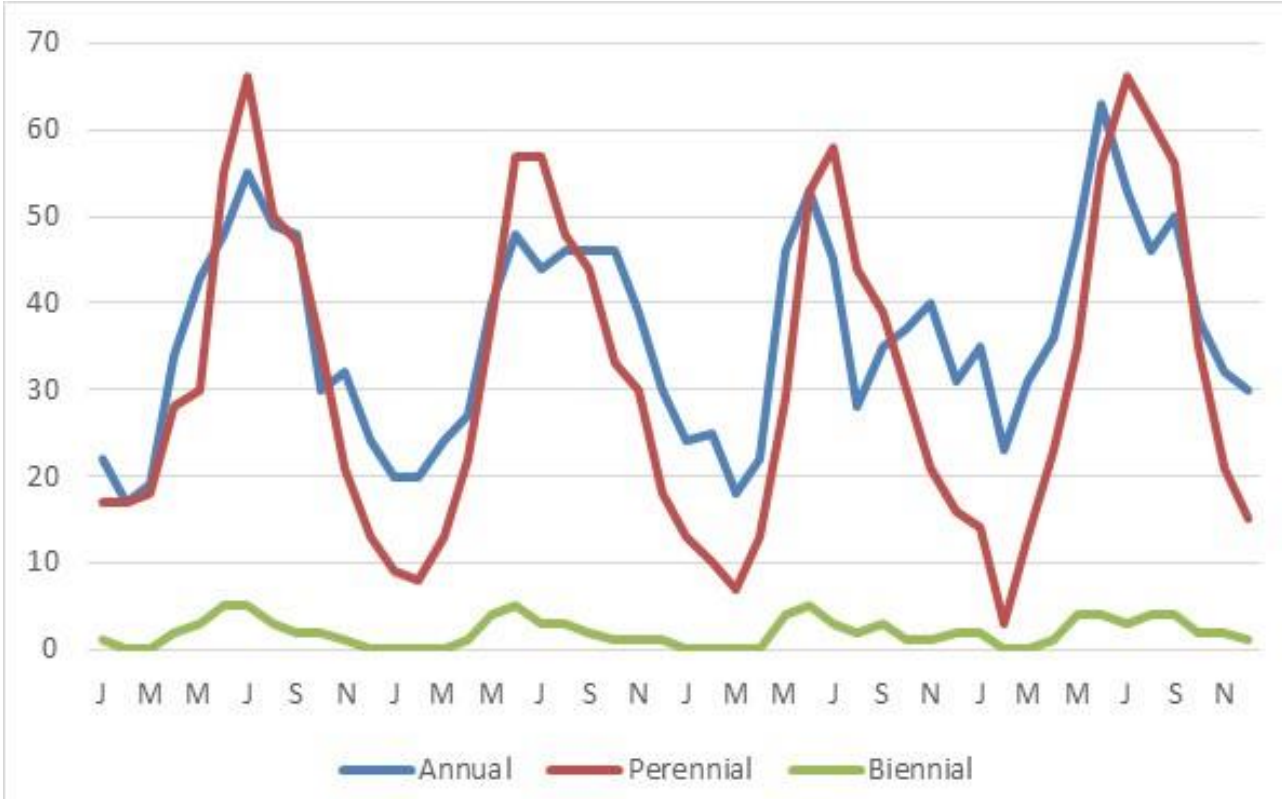

Figure 7. The monthly totals of flowering annual, biennial and perennial species recorded in the transect, 2016-2019.

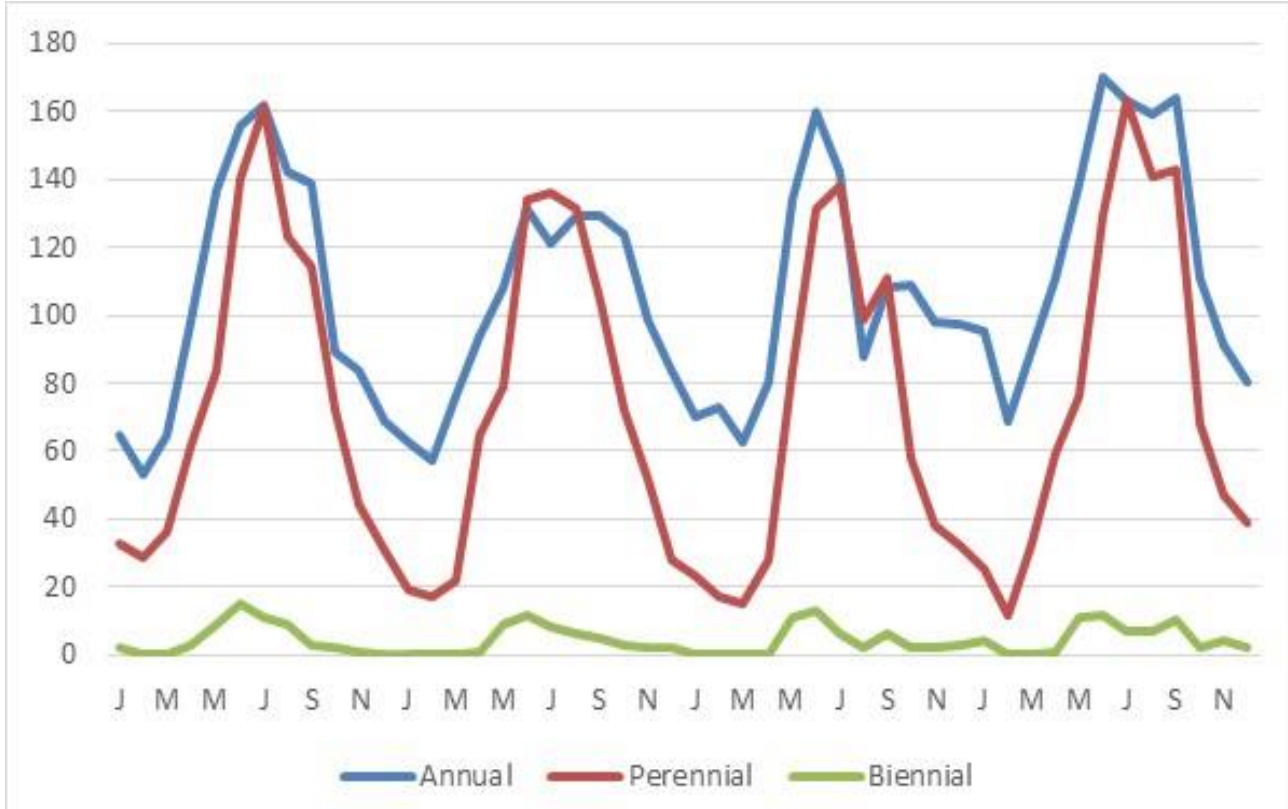

Figure 8. The section totals of flowering annual, biennial and perennial species recorded in the transect, 2016-2019. 


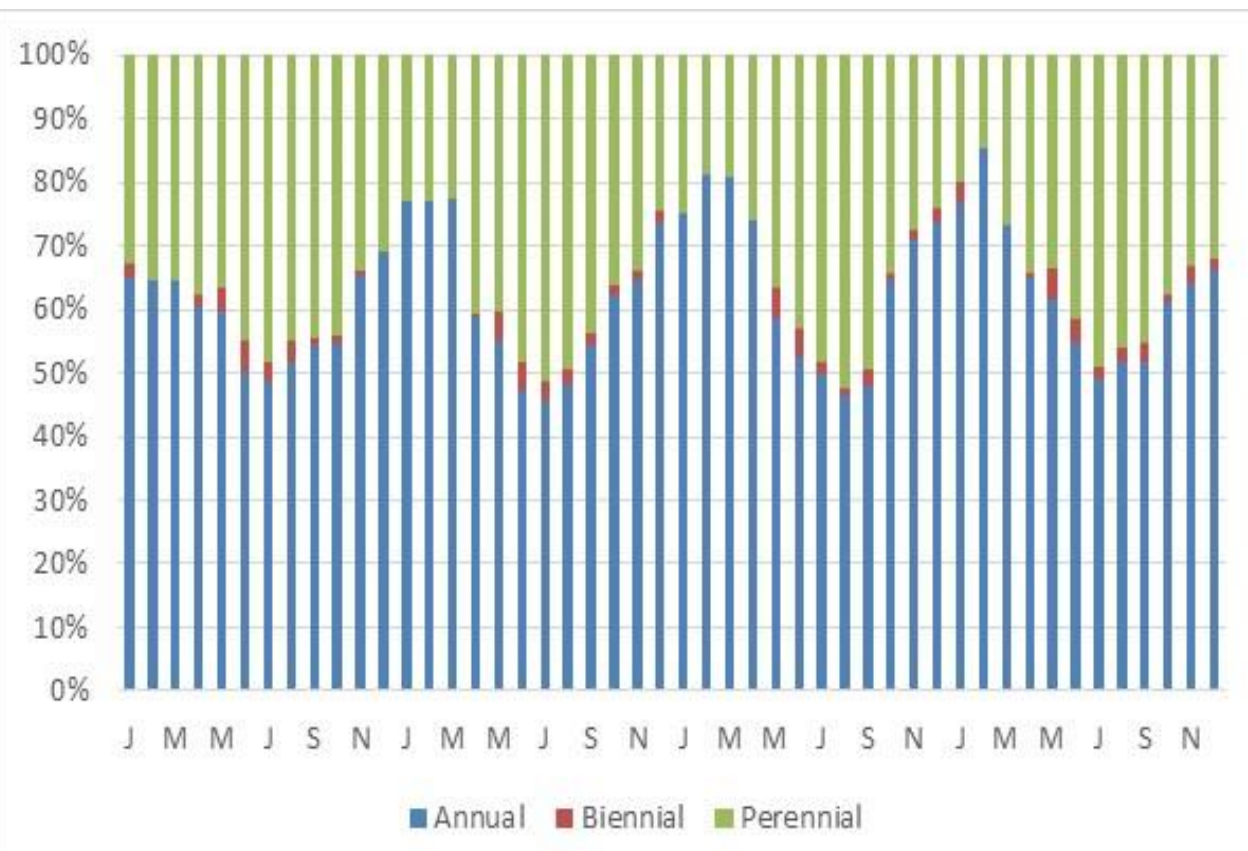

Figure 9. The monthly section totals, expressed as percentages, for flowering annual, biennial and perennial species recorded in the transect, 2016-2019.

Perennial species show greater fluctuations in flowering behaviour than annuals, whether measured by the species or the section totals. In February and March, when fewest plants are flowering, annuals are the larger category and in the cold February of 2018 the totals for flowering perennials fell to the lowest recorded during the four years of the survey. The number of flowering perennials increases rapidly in spring and by the time of the peak in flowering in early summer the number of perennial species exceeds that of the annuals and the section totals are broadly similar. Biennials are a small group and cease flowering completely in the depths of the winter. The only biennial which is at all frequent is Geranium robertianum, which accounts for over half the section records for biennials.

Corresponding diagrams for native, archaeophyte and neophyte species are provided as Figs. 10-12. The classification of species follows Hill et al. (2004) with 'native or alien' (doubtfully native) species treated as natives and casuals as neophytes. The classification applies to Britain and Ireland as a whole, so that species such as Aquilegia vulgaris, Hypericum androsaemum and Papaver cambricum are treated as native even though the plants in Cambridge are clearly garden escapes.

The number of native species usually exceeds the combined number of archaeophytes and neophytes (Figs. 10-12), and the disparity is greatest in the early summer. However, the number of flowering natives falls more rapidly after this early summer peak so that sometimes for a brief period in late autumn the natives are outnumbered by the introduced species. The number of neophytes declines later in the summer and may fall to a very low total in the late winter. Archaeophytes fluctuate less than the other two groups. The native species usually account for at least $50 \%$ of the section records because the fall in the proportion of native annuals in the summer is compensated for by the rise in the proportion of perennials, whereas as winter approaches the reverse is the case. 


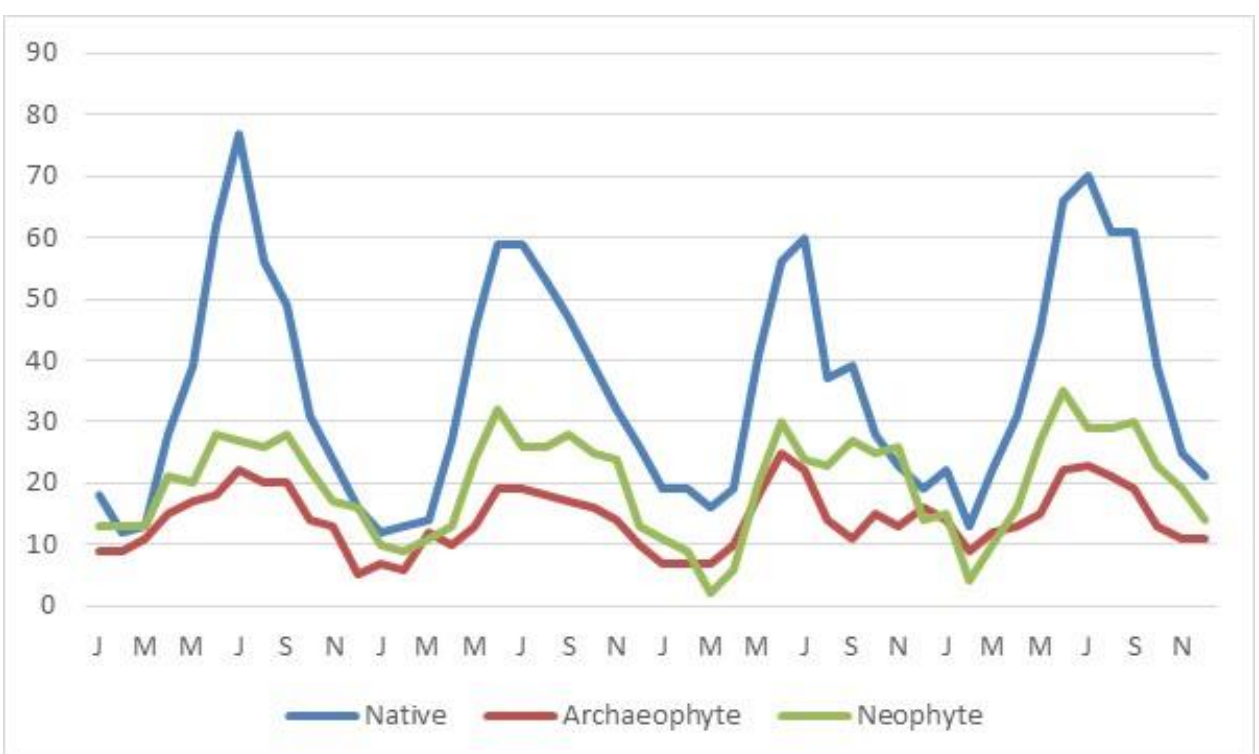

Figure 10. The monthly totals of flowering native, archaeophyte and neophyte species recorded in the transect, 2016-2019.

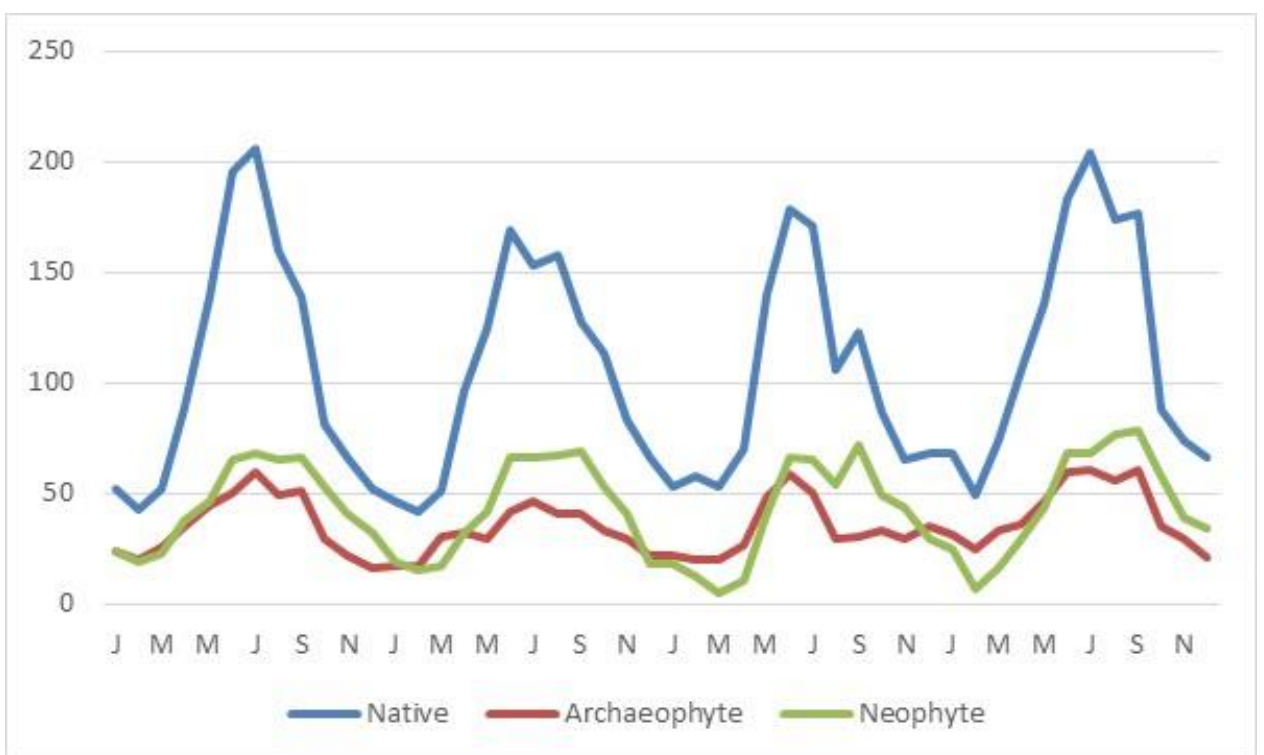

Figure 11. The section totals of flowering native, archaeophyte and neophyte species recorded in the transect, 2016-2019.

\section{Phenology of individual species}

I recorded 74 species flowering in 32 or more sections of the transects in 2016-19, and the phenology of these species is examined below.

Whatever the time of year, six species, Poa annua, Parietaria judaica, Senecio vulgaris, Stellaria media, Euphorbia peplus and Capsella bursa-pastoris, can be found flowering in most streets (Table 3). They are therefore much the most frequent plants recorded in the study. The remaining seven species listed in Table 3 can also be found flowering in almost all months but the figures suggest that the frequency of flowering tends to fall off for a few months in summer or autumn. This phenology can be explained by the death of these annuals when conditions are dry (typically in 
summer) and their regeneration from seed and rapid initiation of flowering when moist conditions return. Species such as Catapodium rigidum (which is represented by subsp. majus in the study area) can however be found flowering in any month, in part because of the unpredictability of rainfall and in part because a few plants sometimes flower in moist or shady corners even as most are succumbing to summer drought.

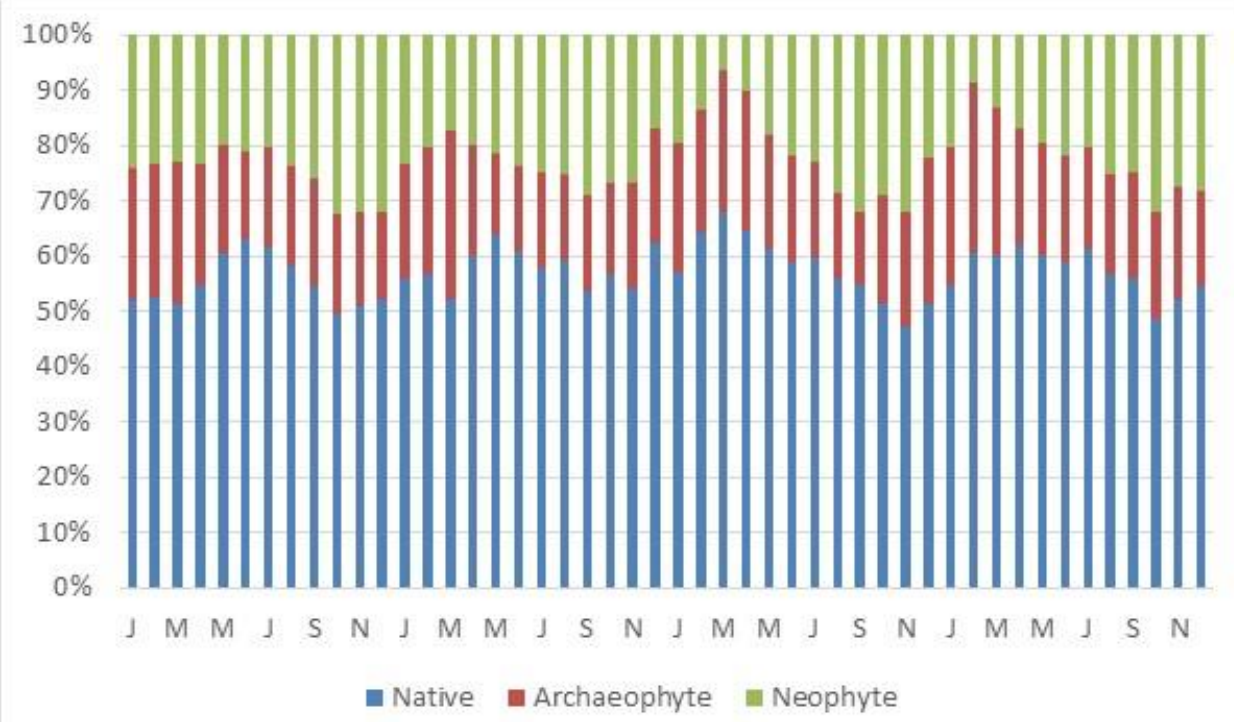

Figure 12. The monthly section totals, expressed as percentages, for flowering native, archaeophyte and neophyte species recorded in the transect, 2016-2019.

Species which have a peak flowering frequency in spring or early summer (March-June) are listed in Table 4. Many of them, although having a discernible peak of flowering in spring, have a diffuse flowering period and indeed 14 of the 26 species in the group have been recorded as flowering in 10-12 months of the year. A few species have an extremely well-defined flowering period and were never recorded flowering outside this, the most notable examples being Erophila verna (January-June), Veronica hederifolia (March-June) and V. arvensis (April-July, rarely into August).

The 35 species flowering later in the year are listed in Table 5 . There are again many with a diffuse flowering period, with half the species in the group recorded in flower in 10-12 months of the year. A few species (e.g. Cymbalaria muralis, Lamium album, Pseudofumaria lutea) are included in this group of later-flowering species rather arbitrarily because of a minor peak in a long flowering period. Another group of species (e.g. Crepis capillaris, Erigeron canadensis, Helminthotheca echioides, Linaria purpurea, Mycelis muralis, Scorzoneroides autumnalis) do not flower in spring, show a peak flowering period in the second half of the summer but then linger on, flowering in smaller quantity, until and in some cases well into the winter. As in the early flowering species, relatively few species have a very well-defined flowering period, most notably the six Epilobium species. 
Table 3. Plants flowering throughout the year, or with reduced flowering in summer. The species listed are drawn from those recorded as flowering in 32 or more of 384 possible sections, 2016-2019. The monthly totals are the percentage of the section records for that species in the month concerned, with periods of reduced flowering shown in bold and the cells shaded. The monthly summary is provided for comparison with that given by Clapham et al. (1952, 1962) in the 'CTW' column.

\begin{tabular}{|c|c|c|c|c|c|c|c|c|c|c|c|c|c|c|c|}
\hline Species & Sections & Jan & Feb & Mar & Apr & May & Jun & Jul & Aug & Sep & Oct & Nov & Dec & Summary & CTW \\
\hline Poa annua & 364 & 9 & 7 & 8 & 9 & 9 & 9 & 9 & 8 & 9 & 8 & 8 & 8 & $1-12$ & $1-12$ \\
\hline Parietaria judaica & 353 & 8 & 7 & 7 & 8 & 9 & 9 & 9 & 8 & 9 & 8 & 9 & 9 & $1-12$ & $6-10$ \\
\hline Senecio vulgaris & 333 & 8 & 8 & 8 & 10 & 9 & 8 & 7 & 9 & 9 & 8 & 8 & 8 & $1-12$ & $1-12$ \\
\hline Stellaria media & 300 & 8 & 8 & 9 & 10 & 9 & 10 & 7 & 7 & 7 & 9 & 8 & 8 & $1-12$ & $1-12$ \\
\hline Euphorbia peplus & 299 & 8 & 8 & 8 & 8 & 8 & 8 & 9 & 9 & 10 & 8 & 8 & 8 & $1-12$ & $4-11$ \\
\hline Capsella bursa-pastoris & 296 & 8 & 7 & 8 & 9 & 9 & 9 & 8 & 8 & 9 & 8 & 9 & 8 & $1-12$ & $1-12$ \\
\hline Urtica urens & 60 & 12 & 8 & 10 & 5 & 5 & 3 & 7 & 7 & 7 & 10 & 13 & 13 & $1-12$ & $6-9$ \\
\hline Euphorbia helioscopia & 42 & 10 & 7 & 10 & 7 & 5 & 2 & 7 & 10 & 10 & 14 & 7 & 12 & $1-12$ & $5-10$ \\
\hline Veronica agrestis & 34 & 12 & 12 & 12 & 15 & 12 & 3 & 0 & 0 & 9 & 3 & 9 & 15 & $1-6,9-12$ & $1-12$ \\
\hline Urtica membranacea & 32 & 9 & 9 & 13 & 13 & 13 & 6 & 3 & 3 & 3 & 6 & 9 & 13 & $1-12$ & - \\
\hline Cardamine hirsuta & 212 & 8 & 9 & 13 & 15 & 14 & 7 & 2 & 4 & 5 & 9 & 7 & 7 & $1-12$ & $4-8$ \\
\hline Veronica polita & 38 & 11 & 5 & 8 & 5 & 8 & 11 & 0 & 5 & 13 & 13 & 13 & 8 & $1-6,8-12$ & $1-12$ \\
\hline Catapodium rigidum & 160 & 9 & 10 & 8 & 8 & 11 & 15 & 13 & 4 & 3 & 4 & 6 & 8 & $1-12$ & $5-6$ \\
\hline
\end{tabular}

Table 4. Plants with a peak flowering period in March to June. The maximum figures for each species are given in bold and the cells shaded. For criteria for inclusion and explanation of columns, see Table 3.

\begin{tabular}{|c|c|c|c|c|c|c|c|c|c|c|c|c|c|c|c|}
\hline Species & Sections & Jan & Feb & Mar & Apr & May & Jun & Jul & Aug & Sep & Oct & Nov & Dec & Summary & CTW \\
\hline Veronica persica & 80 & 6 & 10 & 18 & 13 & 11 & 5 & 3 & 5 & 8 & 6 & 6 & 10 & $1-12$ & $1-12$ \\
\hline Cerastium glomeratum & 41 & 7 & 10 & 12 & 34 & 29 & 2 & 0 & 0 & 0 & 0 & 2 & 2 & $1-6,11-12$ & $4-9$ \\
\hline Erophila verna & 66 & 6 & 12 & 21 & 29 & 27 & 5 & 0 & 0 & 0 & 0 & 0 & 0 & $1-6$ & $3-6$ \\
\hline Lamium purpureum & 129 & 9 & 9 & 12 & 16 & 9 & 5 & 5 & 7 & 8 & 6 & 8 & 5 & $1-12$ & $3-10$ \\
\hline Veronica hederifolia & 69 & 0 & 0 & 19 & 36 & 33 & 12 & 0 & 0 & 0 & 0 & 0 & 0 & $3-6$ & $(3-) 4-5(-8)$ \\
\hline Taraxacum agg & 196 & 3 & 4 & 9 & 14 & 14 & 10 & 8 & 7 & 10 & 8 & 7 & 7 & $1-12$ & $3-10$ \\
\hline
\end{tabular}




\begin{tabular}{|c|c|c|c|c|c|c|c|c|c|c|c|c|c|c|c|}
\hline Soleirolia soleirolii & 55 & 2 & 5 & 9 & 20 & 20 & 20 & 15 & 7 & 0 & 2 & 0 & 0 & $1-8,10$ & $5-10$ \\
\hline Arabidopsis thaliana & 64 & 6 & 5 & 6 & 23 & 28 & 9 & 3 & 2 & 2 & 6 & 5 & 5 & $1-12$ & $4-5(9-10)$ \\
\hline Geranium robertianum & 122 & 4 & 0 & 0 & 3 & 18 & 16 & 16 & 13 & 11 & 6 & 7 & 5 & $1,4-12$ & $5-9$ \\
\hline Veronica arvensis & 55 & 0 & 0 & 0 & 11 & 38 & 35 & 15 & 2 & 0 & 0 & 0 & 0 & $4-8$ & $3-10$ \\
\hline Galium aparine & 58 & 0 & 0 & 0 & 0 & 41 & 41 & 14 & 0 & 2 & 2 & 0 & 0 & $5-7,9-10$ & $6-8$ \\
\hline Medicago arabica & 37 & 3 & 0 & 3 & 16 & 27 & 27 & 8 & 3 & 5 & 3 & 5 & 0 & $1,3-11$ & $4-8$ \\
\hline Pentaglottis sempervirens & 153 & 4 & 3 & 5 & 12 & 16 & 16 & 12 & 7 & 8 & 7 & 5 & 5 & $1-12$ & $5-6$ \\
\hline Anisantha sterilis & 51 & 0 & 0 & 2 & 2 & 37 & 39 & 20 & 0 & 0 & 0 & 0 & 0 & $3-7$ & $5-7$ \\
\hline Bellis perennis & 131 & 8 & 8 & 11 & 10 & 11 & 12 & 8 & 5 & 8 & 5 & 7 & 7 & $1-12$ & $3-10$ \\
\hline Cerastium fontanum & 34 & 6 & 3 & 3 & 3 & 9 & 24 & 9 & 9 & 9 & 9 & 12 & 6 & $1-12$ & $4-9$ \\
\hline Chelidonium majus & 37 & 5 & 3 & 0 & 8 & 19 & 24 & 19 & 5 & 8 & 5 & 0 & 3 & $1-2,4-10,12$ & $5-8$ \\
\hline Erodium moschatum & 34 & 0 & 3 & 9 & 12 & 12 & 15 & 12 & 12 & 12 & 9 & 6 & 0 & $2-11$ & $5-7$ \\
\hline Geranium molle & 68 & 0 & 1 & 0 & 6 & 19 & 24 & 19 & 10 & 9 & 6 & 3 & 3 & $2,4-12$ & $4-9$ \\
\hline Geranium pusillum & 59 & 7 & 3 & 2 & 3 & 14 & 29 & 15 & 5 & 8 & 3 & 5 & 5 & $1-12$ & $6-9$ \\
\hline Geum urbanum & 47 & 0 & 0 & 0 & 0 & 9 & 45 & 21 & 13 & 4 & 6 & 2 & 0 & $5-11$ & $6-8$ \\
\hline Myosotis arvensis & 40 & 5 & 5 & 5 & 0 & 13 & 20 & 10 & 15 & 8 & 5 & 8 & 8 & $1-3,5-12$ & $4-9$ \\
\hline Sagina procumbens & 144 & 0 & 0 & 3 & 8 & 19 & 20 & 17 & 13 & 13 & 6 & 1 & 0 & $3-11$ & $5-9$ \\
\hline Hordeum murinum & 94 & 0 & 0 & 0 & 0 & 5 & 27 & 27 & 18 & 12 & 9 & 2 & 1 & $5-12$ & $6-7$ \\
\hline Centranthus ruber & 33 & 6 & 0 & 0 & 3 & 3 & 21 & 15 & 21 & 15 & 9 & 6 & 0 & $1,4-11$ & $6-8$ \\
\hline Malva neglecta & 34 & 3 & 0 & 0 & 0 & 0 & 21 & 15 & 18 & 21 & 15 & 6 & 3 & $1,6-12$ & $6-9$ \\
\hline
\end{tabular}

Table 5. Plants with a peak flowering period in July to October. The maximum figures for each species are given in bold. For criteria for inclusion and explanation of columns, see Table 3.

\begin{tabular}{|c|c|c|c|c|c|c|c|c|c|c|c|c|c|c|c|}
\hline Species & Sections & Jan & Feb & Mar & Apr & May & Jun & Jul & Aug & Sep & Oct & Nov & Dec & Summary & CTW \\
\hline Cymbalaria muralis & 143 & 2 & 2 & 2 & 8 & 13 & 14 & 15 & 11 & 11 & 9 & 7 & 6 & $1-12$ & $5-9$ \\
\hline Epilobium ciliatum & 93 & 0 & 0 & 0 & 0 & 1 & 13 & 28 & 26 & 22 & 10 & 1 & 0 & $5-11$ & $6-8$ \\
\hline Epilobium montanum & 61 & 0 & 0 & 0 & 0 & 2 & 23 & 28 & 18 & 21 & 5 & 3 & 0 & $5-11$ & $6-8$ \\
\hline Lapsana communis & 102 & 4 & 3 & 2 & 3 & 3 & 14 & 23 & 17 & 13 & 6 & 7 & 7 & $1-12$ & $7-9$ \\
\hline Lobelia erinus & 61 & 7 & 7 & 3 & 5 & 5 & 11 & 21 & 10 & 10 & 8 & 7 & 7 & $1-12$ & - \\
\hline
\end{tabular}




\begin{tabular}{|c|c|c|c|c|c|c|c|c|c|c|c|c|c|c|c|}
\hline Lolium perenne & 66 & 0 & 0 & 0 & 0 & 2 & 27 & 32 & 18 & 17 & 3 & 2 & 0 & 5-11 & $5-8$ \\
\hline Malva sylvestris & 42 & 2 & 2 & 2 & 2 & 0 & 12 & 26 & 21 & 14 & 10 & 5 & 2 & $1-4,6-12$ & $6-9$ \\
\hline Matricaria discoidea & 105 & 2 & 1 & 0 & 1 & 4 & 17 & 25 & 16 & 15 & 9 & 7 & 4 & $1-2,4-12$ & $6-7$ \\
\hline Medicago lupulina & 120 & 2 & 2 & 1 & 2 & 4 & 17 & 23 & 18 & 16 & 9 & 6 & 3 & $1-12$ & $4-8$ \\
\hline Polypogon viridis & 75 & 8 & 4 & 3 & 1 & 1 & 13 & 17 & 13 & 13 & 11 & 7 & 8 & $1-12$ & $6-7$ \\
\hline Sisymbrium officinale & 102 & 2 & 1 & 0 & 1 & 5 & 25 & 27 & 15 & 16 & 4 & 3 & 2 & $1-2,4-12$ & $6-7$ \\
\hline Sonchus asper & 54 & 0 & 0 & 0 & 0 & 7 & 17 & 24 & 20 & 13 & 7 & 6 & 6 & $5-12$ & $6-8$ \\
\hline Trifolium repens & 43 & 0 & 0 & 0 & 0 & 0 & 30 & 40 & 21 & 7 & 2 & 0 & 0 & $6-10$ & $6-9$ \\
\hline Sonchus oleraceus & 213 & 4 & 1 & 0 & 2 & 8 & 12 & 13 & 13 & 13 & 11 & 12 & 10 & $1-2,4-12$ & $6-8$ \\
\hline Crepis capillaris & 61 & 5 & 2 & 0 & 0 & 2 & 5 & 28 & 30 & 13 & 8 & 3 & 5 & $1-2,5-12$ & $6-9$ \\
\hline Epilobium parviflorum & 63 & 0 & 0 & 0 & 0 & 0 & 8 & 29 & 32 & 29 & 3 & 0 & 0 & $6-10$ & $7-8$ \\
\hline Epilobium roseum & 32 & 0 & 0 & 0 & 0 & 0 & 0 & 25 & 34 & 19 & 13 & 9 & 0 & $7-11$ & $7-8$ \\
\hline Epilobium tetragonum & 61 & 0 & 0 & 0 & 0 & 0 & 7 & 30 & 34 & 20 & 10 & 0 & 0 & $6-10$ & $7-8$ \\
\hline Erigeron canadensis & 64 & 0 & 0 & 0 & 0 & 0 & 2 & 14 & 30 & 27 & 17 & 8 & 3 & $6-12$ & $8-9$ \\
\hline Plantago major & 112 & 0 & 0 & 0 & 0 & 0 & 10 & 24 & 28 & 27 & 11 & 1 & 0 & $6-11$ & $5-9$ \\
\hline Pseudofumaria lutea & 169 & 5 & 1 & 1 & 5 & 11 & 11 & 11 & 12 & 12 & 11 & 11 & 9 & $1-12$ & $5-8$ \\
\hline Chenopodium album & 45 & 0 & 0 & 0 & 0 & 0 & 0 & 11 & 16 & 31 & 20 & 13 & 9 & $7-12$ & $7-10$ \\
\hline Epilobium hirsutum & 38 & 0 & 0 & 0 & 0 & 0 & 0 & 8 & 37 & 47 & 8 & 0 & 0 & $7-10$ & $7-8$ \\
\hline Erigeron karvinskianus & 35 & 6 & 6 & 3 & 0 & 9 & 11 & 11 & 9 & 17 & 11 & 9 & 9 & $1-3,5-12$ & $7-8$ \\
\hline Helminthotheca echioides & 50 & 2 & 0 & 0 & 0 & 0 & 0 & 14 & 24 & 30 & 16 & 12 & 2 & $1,7-12$ & $6-10$ \\
\hline Lamium album & 37 & 5 & 3 & 8 & 11 & 11 & 11 & 11 & 8 & 14 & 5 & 8 & 5 & $1-12$ & $5-12$ \\
\hline Linaria purpurea & 69 & 0 & 0 & 0 & 0 & 0 & 12 & 19 & 16 & 20 & 16 & 13 & 4 & $6-12$ & $6-8$ \\
\hline Mycelis muralis & 46 & 4 & 0 & 0 & 0 & 0 & 4 & 24 & 20 & 26 & 13 & 4 & 4 & $1,6-12$ & $7-9$ \\
\hline Oxalis corniculata & 165 & 3 & 1 & 1 & 5 & 10 & 12 & 11 & 15 & 17 & 13 & 8 & 5 & $1-12$ & $6-9$ \\
\hline Polygonum aviculare & 187 & 5 & 2 & 1 & 0 & 0 & 9 & 16 & 16 & 17 & 15 & 10 & 10 & $1-3,6-12$ & $7-10$ \\
\hline Polygonum depressum & 58 & 0 & 0 & 0 & 0 & 0 & 2 & 17 & 21 & 33 & 22 & 5 & 0 & $6-11$ & - \\
\hline Scorzoneroides autumnalis & 36 & 0 & 0 & 0 & 0 & 0 & 0 & 6 & 25 & 36 & 17 & 11 & 6 & $7-12$ & $6-10$ \\
\hline Verbena bonariensis & 50 & 4 & 0 & 0 & 0 & 2 & 6 & 14 & 14 & 18 & 16 & 16 & 10 & $1,5-12$ & - \\
\hline Viola $\mathrm{x}$ wittrockiana & 35 & 0 & 0 & 3 & 3 & 6 & 3 & 11 & 14 & 20 & 20 & 14 & 6 & 3-12 & - \\
\hline $\begin{array}{l}\text { Erigeron } \\
\text { floribundus/sumatrensis }\end{array}$ & 197 & 12 & 7 & 6 & 4 & 3 & 1 & 3 & 11 & 14 & 15 & 14 & 12 & $1-12$ & - \\
\hline
\end{tabular}




\section{Relationship of flowering patterns to reproductive biology}

In the case of some well-studied species, the phenology observed in the streets of Cambridge can be explained by the results of experimental studies of their reproductive biology and physiology. Four of the six species which are common and flower throughout the year, Capsella bursa-pastoris, Poa annua, Senecio vulgaris and Stellaria media, are predominantly self-pollinating annuals; they are capable of flowering whatever the day length, produce seed with no innate dormancy and can complete their life cycle (from germination to seed maturation) in 1-2 months (Aksoy et al., 1998; Hutchinson \& Seymour, 1982; Robinson et al., 2003; Turkington et al., 1980). Hurka et al. (1976) found that flowering in Capsella was promoted by long days, which perhaps indicates that there is variation between genotypes as their conclusion appears to be at variance with other studies and with field experience. Euphorbia pep/us is less well-studied but its biology is broadly similar; it is certainly a self-compatible annual (Asenbaum, 2016) with seeds which have no innate dormancy, although Roberts \& Boddrell (1983) found that seed sown outdoors in 1969-72 showed peak germination in spring and no germination in the winter months. The sixth species, Parietaria judaica, is exceptional in being a perennial with protogynous flowers which are adapted to wind pollination, although it is self-compatible (Franchi et al., 2007). Its long flowering period has been noted in warmer climates, as in Thessaloniki, Greece (Fotiou et al., 2011) and Sydney, Australia (Bass \& Bass, 1990), where it has been studied because of its allergenic pollen.

In contrast to these species, Erophila verna, Veronica arvensis and $V$. hederifolia are winter annuals with restricted flowering seasons, a phenology which is largely governed by their germination requirements. Their seed is shed in spring and is dormant but their dormancy is lost during the summer and they become capable of germination at low but not high temperatures (Baskin \& Baskin, 1970, 1983; Roberts \& Lockett, 1978). There is some evidence that Veronica arvensis, unlike Erophila verna, may require long days for the initiation of flowering (Ratcliffe, 1961) and Grime et al. (1988) have noted that it is one of the later spring annuals to flower.

The well-defined, late flowering season of the perennial Epilobium species is attributable to their requirement for long days to initiate flowering. This has been shown experimentally for several of the species recorded in Cambridge, including $E$. ciliatum, E. hirsutum, E. montanum and E. parviflorum (Myerscough \& Whitehead, 1967; Schwabe, 1989a, 1989b; Shamsi, 1976). Estimates of the minimum daylength required by E. ciliatum vary from 13.5 hours (Przepiorkowski, 2000) to c.16 hours (Schwabe, 1989a) but there is agreement that the longer the day, the more rapidly the plants progress to flowering. In Cambridge 13.5 hours of daylight is attained on 14 April whereas 16 hours is not reached until 21 May, values which are consistent with the start of flowering of this species in May (rarely) or June, and the peak flowering in July. Other species with flowering which requires or at least is promoted by long days include Galium aparine (Weide, 1992), a relatively early flowering species in Cambridge streets, and the later flowering Erigeron canadensis (Zinzolker et al., 1985) and Mycelis muralis (Clabby \& Osborne, 1999). By contrast, Polygonum aviculare flowers late as it is a summer annual, with seed which requires chilling in moist conditions to break its dormancy and therefore does not germinate until spring (Costea \& Tardif, 2005). Chenopodium album is also a summer annual, 
but its flowering is promoted by a reduction in day length (Bassett \& Crompton, 1978; Grime et al., 1988; Roberts, 1964) and it is therefore a late flowerer (although I recorded some plants in flower in early July, which is slightly puzzling). Flowering in C. album continues to December. A minority of Erigeon canadensis and Mycelis muralis plants can stagger on flowering into the winter and some plants of Polygonum aviculare may even survive in flower through the winter to the early spring.

\section{Discussion}

\section{The transect method}

The transect method outlined here is broadly comparable to the method adopted by the Butterfly Monitoring Scheme (BMS), described by Pollard \& Yates (1993) and Sevilleja et al. (2019). In the BMS, butterflies are recorded if they are observed within a fixed distance of an observer walking along a fixed route. I recorded flowering plants in a transect of fixed length and a width which was determined by that of the street. The limits of recording are obvious when the street is lined by houses, whether or not these have gardens. In other places the rule that areas accessible to the public are recorded and private areas are not recorded is usually sufficient to establish the limit. There are some liminal areas such as forecourts of shops, the entrance of gravel paths between houses or (in the Chesterton Road section of the Cambridge transect) the grassy bank of the River Cam. Arbitrary decisions have to be made about whether to include or exclude these areas but when a route is walked monthly by a single observer it is easy to decide initially whether or not to record them and then to follow that decision in subsequent months.

Some flowering plants are undoubtedly under-represented on the transect, particularly those such as Papaver species which produce a few, large but short-lived flowers (Fig. 13). Several individual poppy plants or small colonies which I knew were present on the transect in a particular season were completely missed as they flowered between the monthly walks. In other cases, the problem is to know whether or not a species is flowering. My rule with grasses was to record them if the inflorescences were green and fresh. Their flowering period might therefore be slightly over-estimated, but an insistence on recording only if anthers or stigmas were protruding from the inflorescence would probably under-estimate the flowering period. Cleistogamous and facultatively cleistogamous species (e.g. Sagina procumbens, Stellaria media, S. pallida) are also problematic; I recorded species as flowering if there were buds, cleistogamous flowers and immature fruits all present and in cases of doubt I pulled apart flowers to make sure they were not in fruit. The chasmogamous flowers of Viola species were recorded but not the cleistogamous flowers. Many species have flowers which close up in dull or cold weather and these were recorded as flowering if the furled petals were visible.

One disadvantage of recording linear habitats is that they are often not assignable to the monads of the national grid and records from them are therefore not easily fed into the usual recording databases with precise grid references. In the Cambridge transect six streets fell within a single monad but the two longest (Chesterton Lane, Victoria Road), although predominantly in one monad, have stretches in another. 


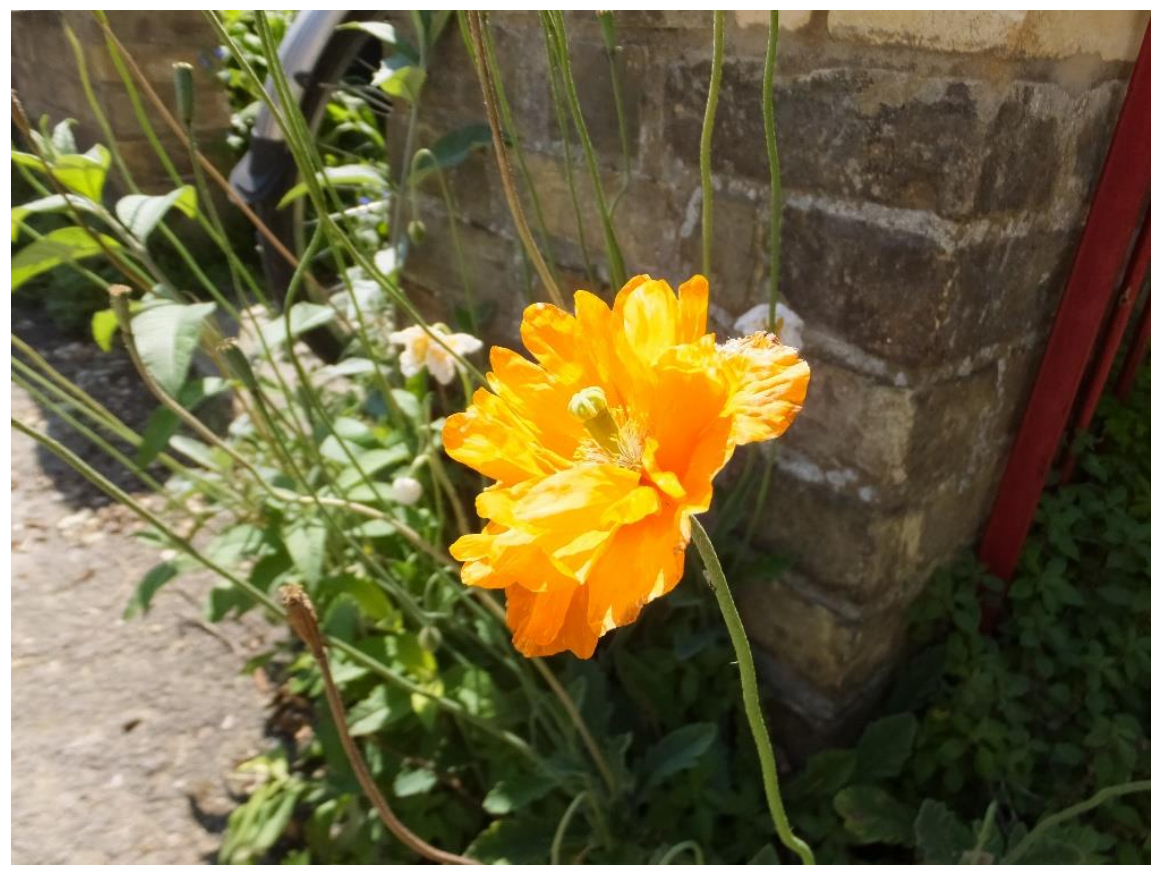

Figure 13. Papaver atlanticum, a species which was probably under-recorded by the transect method, Green's Road, 6 June 2016.

Transects have been used occasionally in other phenological studies, but these have usually been set up to study variation in differing climates or microclimates over substantial latitudinal or altitudinal gradients. In some cases, the phenology of vegetation has been monitored by remote sensing techniques (Ma et al., 2013; Wang et al., 2017) but studies with more similarities to the current one have been carried out along hiking trails in North America. An outstanding example is a longterm (27 year) study of the flowering of 558 plant species along an $8 \mathrm{~km}$ trail in Arizona which spans an altitudinal range of $1200 \mathrm{~m}$ (Crimmins et al., 2013). Intensive but short-term studies have also been made along trails in the Acadia National Park, Maine, by McDonough MacKenzie et al. (2019), who recorded numerous phenological events for 30 taxa, and along transects in the Bavarian Alps, where Schuster et al. (2014) recorded the leaf development and senescence of seven tree species.

\section{Possible modifications of the method}

A major difference between the Butterfly Monitoring Scheme and the transect scheme described here is that BMS recorders count the number of individual butterflies whereas in the current study I have recorded simply the presence of flowering plants in transect sections. The section totals summarised as percentages in Tables 3-5 give a numerical indication of the peak flowering time for many species but it is possible that a count of flowering individuals would reveal that the numbers of plants flowering outside the main season are rather small, and that consequently the peak flowering periods are more marked than the percentages suggest. An obvious question is therefore whether the number of flowering individuals might be counted along the transect. Most species present in these urban habitats are in theory countable, although there are practical difficulties if plants 
grow in dense swards, or if they are cleistogamous and require individuals to be examined closely to check whether they are in flower. (There are species, such as some grasses and Soleirolia soleirolii, which form dense mats in which individuals cannot be identified.) However, the manual for BMS recorders emphasises that a transect "should not be a tedious and dull activity that requires a lot of effort" (Sevilleja et al., 2019). Counting the number of individuals would certainly extend the time needed to record the Cambridge transect (even if its length was reduced) and almost certainly render the recording tedious and dull. In some studies, the number of flowering plants has been assessed on a scale which combines the number of blooms and their percentage cover (Roy et al., 2003) but the cover of even the most frequent street weeds is generally very low. It might be possible to record whether plants are present as, say, 1, 2-5 or $>5$ flowering individuals or clumps. However, it would be easier to increase the number of sections by recording both sides of the streets separately, by dividing up the longer sections, or by adding new streets to the route. In addition, a sample of conspicuous species might be counted to investigate the relationship between peaks in section totals and the number of flowering individuals.

In a single study such as this, the variation in length of the transect sections is perhaps of little moment; it is more important to record the sections consistently between visits. If such recording was carried out on a broader scale it would probably be desirable to suggest a standard length for the sections. However, it is less feasible to control the width of the transects in a street than it is on walks such as those for the BMS, and even if the width was standardised the number of habitats included on transects would be very variable, so that sections of equal length and width would be very different in other respects.

\section{Factors affecting the street flora}

During the four years of recording, two factors have most obviously influenced the seasonal progression of flowering. The first is the weather, and in particular severe winter weather and summer drought. The most severe winter weather in the recording period was in February and March 2018 (see Martyr, 2019) and this is the reason why the minimum monthly total in 2018 was in March rather than in February as in the other years. This was followed in 2018 by a drought in the early summer, with virtually no rain in June $(0.8 \mathrm{~mm}$ in Cambridge Botanic Garden, $2.5 \mathrm{~km}$ away) and very little in July $(12.2 \mathrm{~mm})$. This extremely dry period was also one in which temperatures were unusually high (Martyr, 2019). Species differed in their response (Figs. 14, 15) but the overall effect can be seen in Fig. 4 as a marked dip in the section total for August 2018 then a recovery to a higher level in September 2018 following wet weather in August $(68.6 \mathrm{~mm})$. The same pattern is visible in some of the totals for individual habitats (Figs. 5, 6), especially those for pavements and gravel areas.

The other factor which influences the flora in the short-term is weed control. The most obvious single annual event is the application by the City Council of weedkiller to the pavements (especially the junction between the pavements and the walls alongside them) in April or May (Fig. 16). This is followed by the death of most of the plants which have received it, although some species are less severely affected. Many plants of Cymbalaria muralis, for example, although showing some leaf damage, gradually recover. The application of weedkiller is also inefficient as 
plants behind parked cars or cycles tend to escape treatment, and species can reinvade from walls and nearby private land, which are not targetted. Herbicide resistance has been reported from several of the species on the Cambridge list, including paraquat resistance in Epilobium ciliatum, Erigeron canadensis and Poa annua in Europe (De Prado et al., 1997) and glyphosate resistance in Erigeron sumatrensis in Europe (Sansom et al., 2013) and E. canadensis in North America (Zelaya et al., 2004) but I do not know if such variants occur in Cambridge. In some years (e.g. 2016) the weedkiller application has been followed a few weeks later by a squad tasked with removing the physical remains of the plants (Fig. 17). This is followed by the death of most of the plants which have received it, although some species are less severely affected. Many plants of Cymbalaria muralis, for example, although showing some leaf damage, gradually recover. The application of weedkiller is also inefficient as plants behind parked cars or cycles tend to escape treatment, and species can re-invade from walls and nearby private land, which are not targetted. Herbicide resistance has been reported from several of the species on the Cambridge list, including paraquat resistance in Epilobium ciliatum, Erigeron canadensis and Poa annua in Europe (De Prado et al., 1997) and glyphosate resistance in Erigeron sumatrensis in Europe (Sansom et al., 2013) and $E$. canadensis in North America (Zelaya et al., 2004) but I do not know if such variants occur in Cambridge. In some years (e.g. 2016) the weedkiller application has been followed a few weeks later by a squad tasked with removing the physical remains of the plants (Fig. 17). Species such as Cardamine hirsuta soon recolonise the cleared areas, presumably from the seed bank, but the weed-killing regime may be partly responsible, along with summer drought, for the reduction in the number of sections with flowering $C$. hirsuta in the summer (Table 3 ). In the last two years particular efforts have also been made to spray round the base of all street trees. Commercial or institutional owners also control street weeds by applications of weedkiller, a notable example being Magdalene College which treats the pavement below the college wall and in front of its student housing on Chesterton Lane. Individual house owners rarely use weedkiller but the redevelopment or refurbishment of properties is often accompanied by physical removal of the street weeds alongside them.

Particularly tidy-minded house owners sometimes routinely eradicate street weeds along their frontages and my impression is that they do a more thorough job than the hireling shepherds of the council.

The number of species recorded on the monthly transects from the flat grass swards in the Mitcham's Corner section is to some extent influenced by the length of time since they were last mown; this is less true of the grass in the Mount Pleasant section, some of which is on a steep bank and is less uniformly mown.

There have been changes to the urban sites recorded during the course of the project, reflecting the increasing development of a prosperous and expanding city and perhaps also the increasing financial constraints on its local authority. Small changes affect the species recorded in individual streets. In Green's Road an area of gravel-covered ground was used as a car park in 2016 and had a rather limited flora along the margins; this has since been closed off and used to store building materials for a local development and has been colonised by a richer flora, and this is reflected in the increasing number of flowering species recorded on gravel in this section (Figs. 18, 19). In the longer term this area will almost certainly be built on. The presence of individual species is sometimes heavily influenced by transient 
features - Erigeron karvinskianus has been recorded consistently in Albert Street but rarely elsewhere simply because seed is shed onto the street from two tubs of the species which have been grown on the pavement throughout the period of the survey. A municipal flower bed in Mitcham's Corner (Fig. 2) had been the stronghold for Galinsoga quadriradiata in the transect but was sown to grass in September 2019.

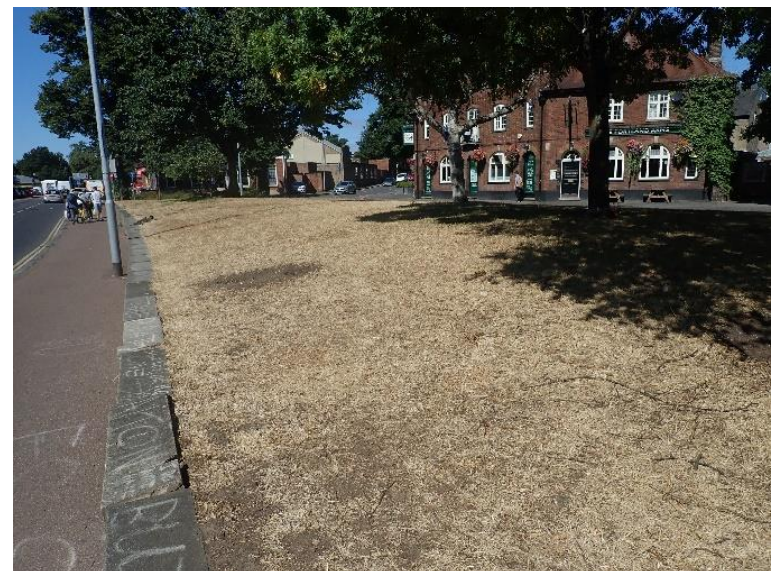

Figure 14. The effects of the $\mathbf{2 0 1 8}$ drought on a grass sward at Mitcham's Corner, 2 August 2018.

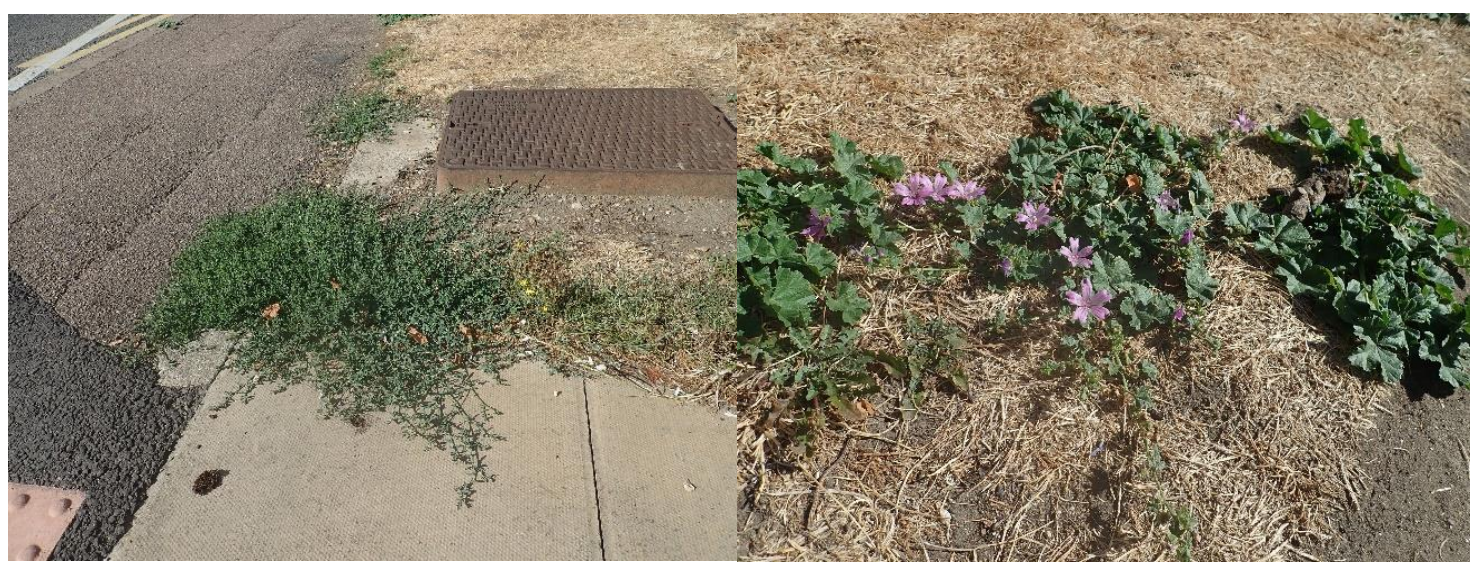

Figure 15. Species flowering despite the drought, 2 August 2018 (left) Polygonum aviculare; (right) Malva sylvestris.

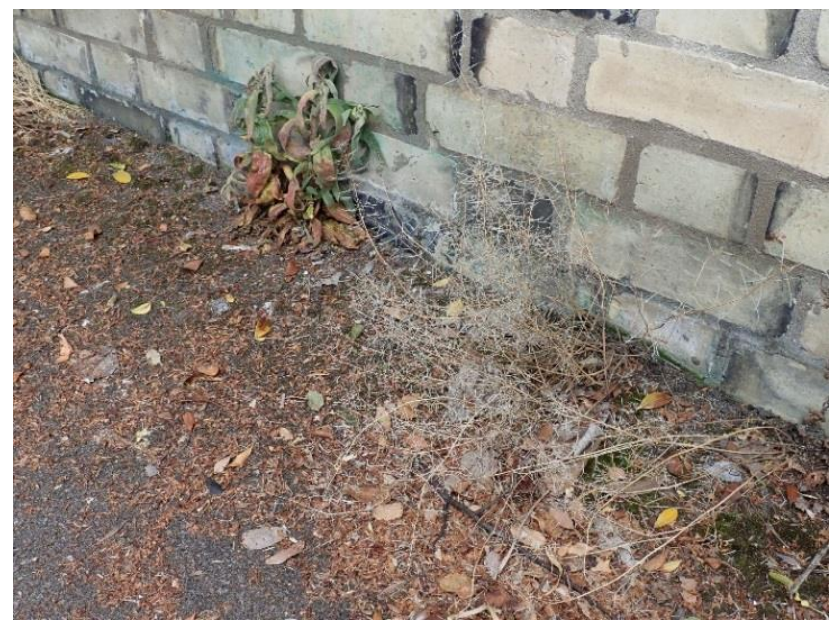

Figure 16. Epilobium (left) dying after the application of weedkiller, 1 June 2018, but Capsella bursa-pastoris (right) has already shed its seed. 


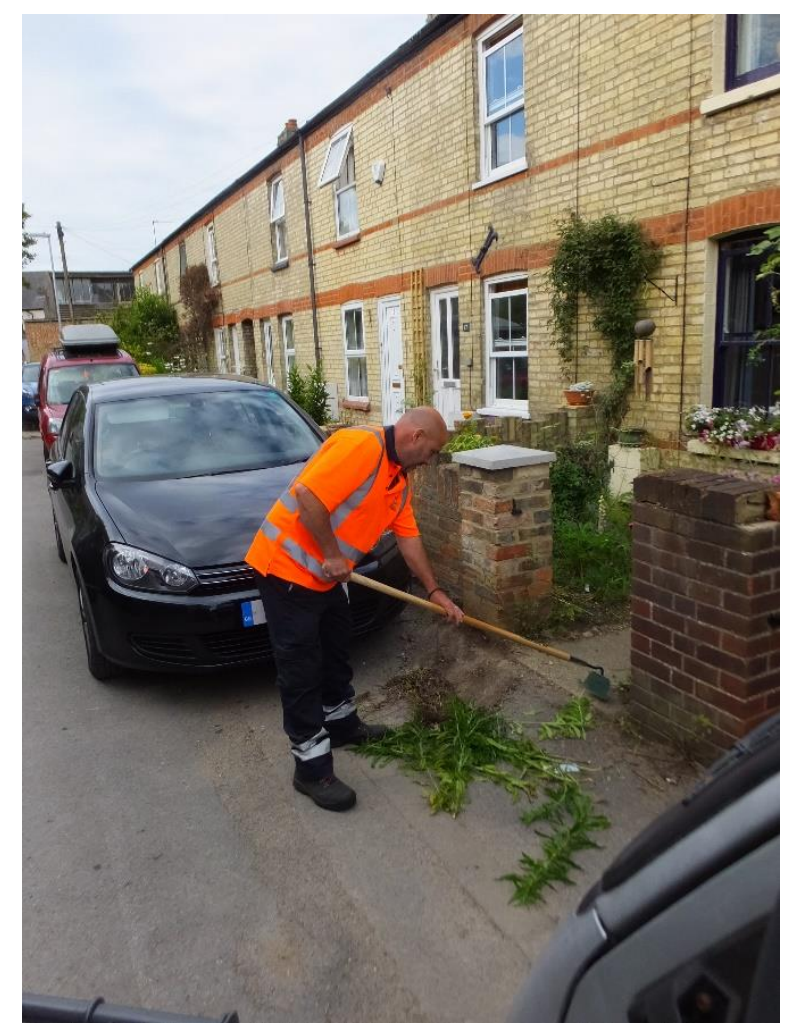

Figure 17. Removal of street weeds which escaped the application of weedkiller, Green's Road, 7 July 2016.

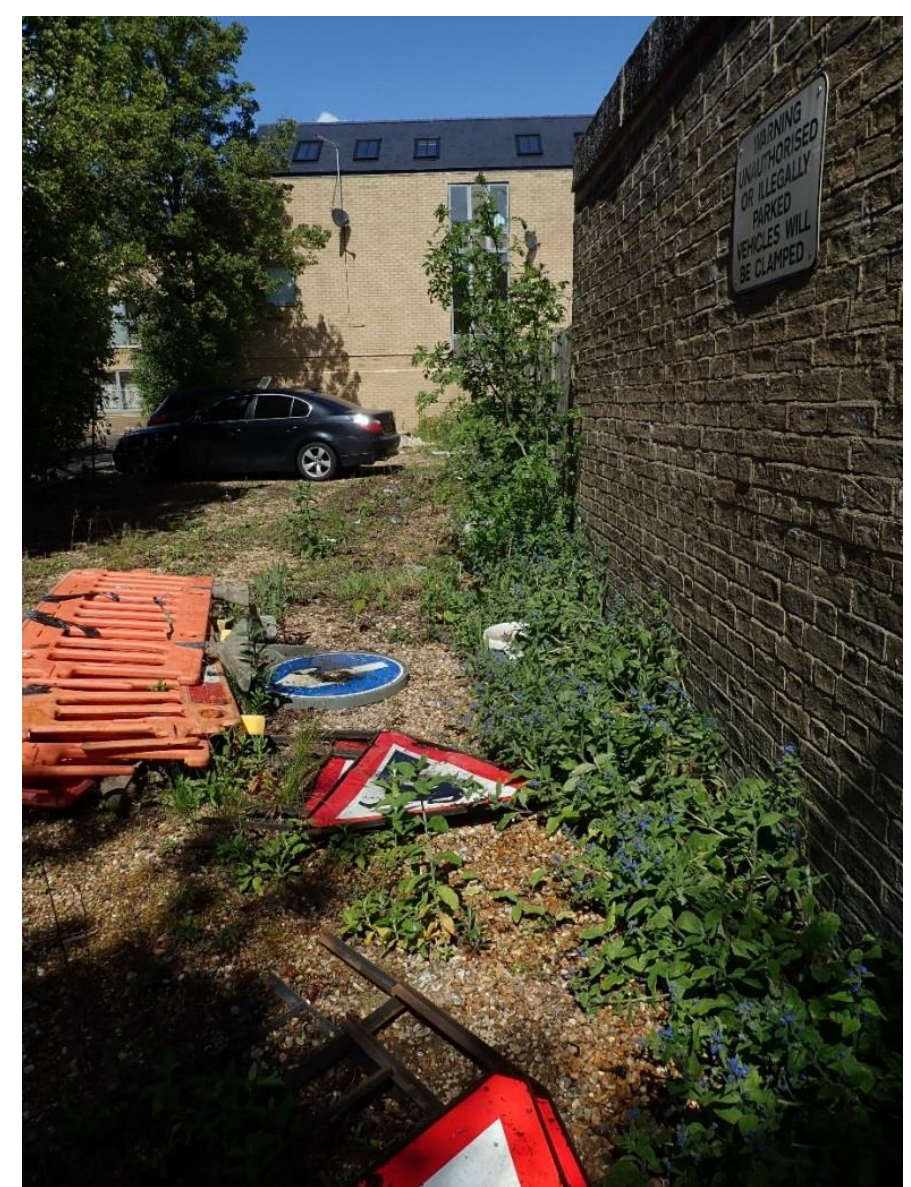

Figure 18. The former car park in Green's Road which became colonised by a wide range of species once it was used as a storage area, 4 May 2019. 


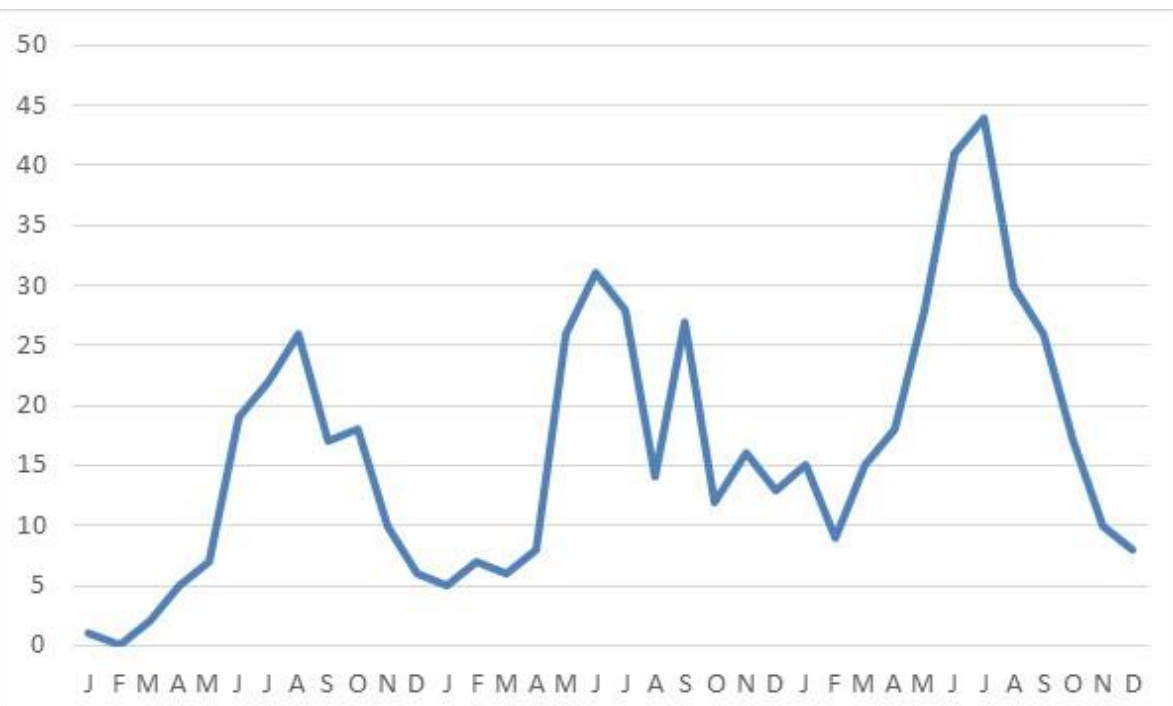

Figure 19. The number of species recorded from gravel-covered ground in Green's Road, 2017-2019.

\section{Comparison of results with flowering times in national Floras}

In Tables 3-5, the months of flowering on the streets studied are compared with those given by Clapham et al. (1952, 1962), perhaps the single source most likely to be consulted for flowering times of British plants. Substantial discrepancies are numerous, and it may therefore still be the case that, as Bennett (1869) remarked 150 years ago, "the time of flowering of our common plants given in our text-books is lamentably inexact". For many species the flowering span reported by Clapham et al. (1962) and Sell \& Murrell (1996-2018) is much shorter than that recorded in the current study (even though these works cover a much wider geographical and ecological range). One therefore gets the overall impression from the floras that plants have a much more circumscribed flowering period than they currently do in the streets of Cambridge. Some species with major discrepancies are neophytes which have increased greatly since the text for the first edition of Clapham et al. was drafted c.1950, and which for this reason might not have been well known to the authors or well represented in herbaria (e.g. Erigeron karvinskianus, Pentaglottis sempervirens, Polypogon viridis), but there are also marked discrepancies for many species which were very widespread in 1950 (e.g. Cardamine hirsuta, Sisymbrium officinale, Urtica urens). Euphorbia peplus, for example, was amongst the species known to Bennett (1869) to "flower and fructify all through the year, almost regardless of season or temperature" but it is nevertheless listed by Clapham et al. (1962) and Sell \& Murrell (2009) as flowering between April and November. Successive Floras are in general agreement over the flowering time of Parietaria judaica, given as June-September by Smith $(1800,1824)$ and Babington (1843) and June-October by Hooker (1870), Clapham et al. (1952), Butcher (1961, as mid-June to mid-October) and Sell \& Murrell (2018), an agreement which would be impressive were it not so far from the truth. Flowering times in floras are usually presented with no explanation of their derivation. I suspect that, if not copied from earlier authors, they were often derived from herbarium specimens and thus have significant inherent biases. So, although it is possible, perhaps even likely, that flowering spans 
have changed over the last two centuries, it would be very unsafe to conclude this from a comparison of current dates with those in published floras.

\section{Conclusions}

The methods of the Butterfly Monitoring Scheme have been shown to identify both national trends and the effect of changes at site level such as management operations on individual sites (Pollard \& Yates, 1993). Similarly, the transect study of plant phenology presented here has identified a consistent pattern of broad seasonal trends in the phenology of the urban flora over a period of four years, and in the case of well-studied species these trends are explicable in terms of our knowledge of the reproductive biology of the species. In addition to showing general trends, the results also show the influence of climatic extremes in individual seasons and the effects of some major changes in the environment of particular streets. These trends emerge despite the unstable nature of the street flora, in which many species are clearly present as sink populations or casual colonists, and subject to constant human interventions such as weed control and grass cutting.

Phenological studies of plants have traditionally concentrated on single events such as the onset of flowering or leafing (Jochner \& Menzel, 2015; Menzel et al., 2006; Roetzer et al., 2000; Sparks \& Carey, 1995). Chapman et al. (2015) have outlined a method for estimating the peak period of flowering of species from biological records, but the utility of this method has not yet been explored in any depth. The transect study reported here is not aimed at identifying first dates, which would require much more frequent sampling, but at establishing the overall span of flowering. Published statements of flowering spans in floras such as Clapham et al. (1962) and Sell \& Murrell (1996-2018) present a single statement of flowering time which does not describe variation in habitat or geographical location. Nevertheless, they are the only data available and as such are perforce used in analysing the results of studies such as the New Year Plant Hunt (Walker \& Marsh, 2019). Investigations of flowering times along the lines of the one presented here offer the possibility of collecting a more reliable corpus of data on flowering spans. If combined together in a national framework, such studies might provide a means of exploring variation in flowering spans both ecologically and geographically, and of documenting changes over time.

\section{Acknowledgements}

I am grateful to Alan Leslie for much help in identifying the more unusual garden escapes encountered on the transect and Joachim Kadereit for confirming the identity of Papaver atlanticum. Pete Stroh helped me to generate the street map and Oli Pescott, David Roy and Kevin Walker kindly provided valuable comments on a draft of this paper.

\section{References}

Aksoy, A., Dixon, J.M. \& Hale, W.H.G. 1998. Capsella bursa-pastoris (L.) Medikus. Biological Flora of the British Isles 199. Journal of Ecology, 86: 171-186.

Asenbaum, J. 2016. Pollination biology of European Euphorbia species. Masterarbeit, University of Vienna.

Babington, C.C. 1843. Manual of British botany. London: John van Voorst. 
Baskin, J.M. \& Baskin, C.C. 1970. Germination eco-physiology of Draba verna. Bulletin of the Torrey Botanical Club, 97: 209-216.

Baskin, J.M. \& Baskin, C.C. 1983. Germination ecology of Veronica arvensis. Journal of Ecology, 71: 57-68.

Bass, D.A. \& Bass, D.J. 1990. Parietaria judaica L. A cause of allergic disease in Sydney. A study of habit and spread of the weed. Review of Palaeobotany and Palynology, 64: 97-101.

Bassett, I.J. \& Crompton, C.W. 1978. The biology of Canadian weeds. 32. Chenopodium album L. Canadian Journal of Plant Science, 58: 1061-1072.

Bennett, A.W. 1869. On the fertilisation of winter-flowering plants. Nature, 1: 11-13.

Butcher, R.W. 1961. A new illustrated British flora. 2 vols. London: Leonard Hill (Books).

Chapman, D.S., Bell, S., Helfer, S. \& Roy, D.B. 2015. Unbiased inference of plant flowering phenology from biological recording data. Biological Journal of the Linnean Society, 115: 543-554.

Clabby, B. \& Osborne, B.A. 1999. Mycelis muralis (L.) Dumort. Biological Flora of the British Isles 204. Journal of Ecology, 87: 156-172.

Clapham, A.R., Tutin, T.G. \& Warburg, E.F. 1952. Flora of the British Isles. Cambridge: Cambridge University Press.

Clapham, A.R., Tutin, T.G. \& Warburg, E.F. 1962. Flora of the British Isles, $2^{\text {nd }}$ ed. Cambridge: Cambridge University Press.

Costea, M. \& Tardif, F.J. 2005. The biology of Canadian weeds. 131. Polygonum aviculare L. Canadian Journal of Plant Science, 85: 481-506.

Crimmins, T.M., Crimmins, M.A. \& Bertelsen, C.D. 2013. Spring and summer patterns in flowering onset, duration, and constancy across a water-limited gradient. American Journal of Botany, 100: 1137-1147.

De Prado, R., Lopez-Martinez, N. \& Giminez-Espinosa, R. 1997. Herbicide-resistant weeds in Europe: agricultural, physiological and biochemical aspects, in R. De Prado, J. Jorrín \& L. Garcia-Torres, eds, Weed and crop resistance to herbicides, pp. 17-27. Dordrecht: Kluwer Academic Publishers.

Fotiou, C., Damialis, A., Krigas, N., Halley, J.M. \& Vokou, D. 2011. Parietaria judaica flowering phenology, pollen production, viability and atmospheric circulation, and expansive ability in the urban environment: impacts of environmental factors. International Journal of Biometeorology, 55: 35-50.

Franchi, G.G., Nepi, M., Matthews, M.L. \& Pacini, E. 2007. Anther opening, pollen biology and stigma receptivity in the long blooming species, Parietaria judaica L. (Urticaceae). Flora, 202: 118-127.

Grime, J.P., Hodgson, J.G. \& Hunt, R. 1988. Comparative plant ecology. London: Unwin Hyman.

Hill, M.O., Preston, C.D. \& Roy, D.B. 2004. PLANTATT Attributes of British and Irish plants: status, size, life history, geography and habitats. Abbots Ripton: Centre for Ecology \& Hydrology.

Hooker, J.D. 1870. The student's flora of the British Islands. London: Macmillan \& Co.

Hurka, H., Krauss, R., Reiner, T. \& Wöhrmann, K. 1976. Das Blühverhalten von Capsella bursa-pastoris (Brassicaceae). Plant Systematics and Evolution, 125: 87-95. 
Hutchinson, C.S. \& Seymour, G.B. 1982. Poa annua L. Biological Flora of the British Isles 153. Journal of Ecology, 70: 887-901.

Jochner, S. \& Menzel, A. 2015. Urban phenological studies - past, present, future. Environmental Pollution, 203: 250-261.

Leslie, A.C. 2019. Flora of Cambridgeshire. Peterborough: Royal Horticultural Society.

Loggan, D. [1690]. Cantabrigia illustrata. Cambridge.

Ma, X., Huete, A., Yu, Q., Coupe, N.R., Davies, K., Broich, M., Ratana, P., Beringer, J., Hutley, L.B., Cleverly, J., Boulain, N. \& Eamus, D. 2013. Spatial patterns and temporal dynamics in savanna vegetation phenology across the North Australian Tropical Transect. Remote Sensing of Environment, 139: 97-115.

Marsh, L. 2016. New Year Plant Hunt 2016: twice as many species as last year and three times as many botanists! BSBI News, 132: 44-48.

Martyr, K. 2019. Weather notes from Cambridge University Botanic Garden, 2018. Nature in Cambridgeshire, 61: 92-93.

McDonough MacKenzie, C., Primack, R.B. \& Miller-Rushing, A.J. 2019. Trails-astransects: phenology monitoring across heterogeneous microclimates in Acadia National Park, Maine. Ecosphere, 10(3): article e02626.

Menzel, A., Sparks, T.H., Estrella, N., Koch, E. et al. 2006. European phenological response to climate change matches the warming pattern. Global Change Biology, 12: 1969-1976.

Myerscough, P.J. \& Whitehead, F.H. 1967. Comparative biology of Tussilago farfara L., Chamaenerion angustifolium (L.) Scop., Epilobium montanum L., and Epilobium adenocaulon Hausskn. II. Growth and ecology. New Phytologist 66: 785-823.

Pollard, E. \& Yates, T.J. 1993. Monitoring butterflies for ecology and conservation: the British Butterfly Monitoring Scheme. London: Chapman \& Hall.

Przepiorkowski, T.M. 2000. Biology of Epilobium ciliatum Rafin. perennating structures. D.Phil. dissertation, Ohio State University.

Ratcliffe, D. 1961. Adaptation to habitat in a group of annual plants. Journal of Ecology, 49: 183-203.

Roberts, H.A. 1964. Emergence and longevity in cultivated soil of seeds of some annual weeds. Weed Research, 4: 296-307.

Roberts, H.A. \& Boddrell, J.E. 1983. Seed survival and periodicity of seedling emergence in ten species of annual weeds. Annals of Applied Biology, 102: 523-532.

Roberts, H.A. \& Lockett, P.A. 1978. Seed dormancy and periodicity of seedling emergence in Veronica hederifolia L. Weed Research, 18: 41-48.

Robinson, D. E., O'Donovan, J. T., Sharma, M. P., Doohan, D. J. \& Figueroa, R. 2003. The biology of Canadian weeds. 123. Senecio vulgaris L. Canadian Journal of Plant Science, 83: 629-644.

Roetzer, T, Wittenzeller, M., Haeckel, H. \& Nekovar, J. 2000. Phenology in central Europe - differences and trends of spring phenophases in urban and rural areas. International Journal of Biometeorology, 44: 60-66.

Roy, D.B., Bohan, D.A., Haughton, A.J., Hill, M.O., Osborne, J.L., Clark, S.J., Perry, J.N., Rothery, P., Scott, R.J., Brooks, D.R., Champion, D.T., Hawes, C., Heard, M.S. \& Firbank, L.G. 2003. Invertebrates and vegetation of field margins adjacent to crops subject to contrasting herbicide regimes in the Farm Scale 
Evaluations of genetically modified herbicide-tolerant crops. Philosophical Transactions of the Royal Society of London B, 358: 1879-1898.

Sansom, M., Saborido, A.A. \& Dubois, M. 2013. Control of Conyza spp. with glyphosate - a review of the situation in Europe. Plant Protection Science, 49: 44-53.

Schuster, C., Estrella, N. \& Menzel, A. 2014. Shifting and extension of phenological periods with increasing temperature along elevational transects in southern Bavaria. Plant Biology, 16: 332-344.

Schwabe, W.W. 1989a. Epilobium adenocaulon, in A.H. Halevy, ed. Handbook of flowering, vol. VI, pp. 307-316. Boca Raton: CRC Press.

Schwabe, W.W. 1989b. Epilobium hirsutum and E. parviflorum, in A.H. Halevy, ed. Handbook of flowering, vol. VI, pp. 317-321. Boca Raton: CRC Press.

Sell, P.D. \& Murrell, G. 1996-2018. Flora of Great Britain and Ireland. 5 vols. Cambridge: Cambridge University Press.

Sevilleja, C.G., van Swaay, C.A.M., Bourn, N., Collins, S., Settele, J., Warren, M.S., Wynhoff, I. \& Roy, D.B. 2019. Butterfly transect counts: manual to monitor butterflies. Wageningen: Butterfly Conservation Europe \& De Vlinderstichting/Dutch Butterfly Conservation.

Shamsi, S.R.A. 1976. Effect of a light-break on the growth and development of Epilobium hirsutum and Lythrum salicaria in short photoperiods. Annals of Botany, 40: 153-162.

Smith, J.E. 1800. Flora Britannica, vol. 1. London: J. Davis.

Smith. J.E. 1824. The English flora, vol. 1. London: Longman, Hurst, Rees, Orme, Brown, \& Green.

Sparks, T.H. \& Carey, P.D. 1995. The responses of species to climate over two centuries: an analysis of the Marsham phenological record, 1736-1947. Journal of Ecology, 83: 321-329.

Stace, C.A. 2019. New Flora of the British Isles, $4^{\text {th }}$ ed. Middlewood Green, Suffolk: C \& M Floristics.

Turkington, R., Kenkel, N.C. \& Franko, G.D. 1980. The biology of Canadian weeds. 42. Stellaria media (L.) Vill. Canadian Journal of Plant Science, 60: 981-992.

Walker, K. \& Marsh, L. 2019. BSBI New Year Plant Hunt 2019. BSBI News, 141: 1418.

Wang, X., Gao, Q., Wang, C. \& Yu, M. 2017. Spatiotemporal patterns of vegetation phenology change and relationships with climate in the two transects of East China. Global Ecology and Conservation, 10: 206-219.

Weide, R.Y. van der 1992. Phenology of arable and hedgerow populations of Galium aparine $\mathrm{L}$. in relation to climate and soil conditions. Weed Research, 32: 249258.

Wright, A.P.M. 1989. Chesterton, in A.P.M. Wright \& C.P. Lewis, eds, $A$ history of the county of Cambridge and the Isle of Ely. Volume IX. Chesterton, Northstowe, and Papworth Hundreds (North and North-west of Cambridge), pp. 5-39. Oxford: Oxford University Press.

Zelaya, I.A., Owen, M.D.K. \& VanGessel, M.J. 2004. Inheritance of evolved glyphosate resistance in Conyza canadensis (L.) Cronq. Theoretical and Applied Genetics, 110: 58-70. 
Zinzolker, A., Kigel, J. \& Rubin, B. 1985. Effects of environmental factors on the germination and flowering of Conyza albida, C. bonariensis and C. canadensis. [Abstract.] Phytoparasitica, 13: 229-230.

Postscript added prior to publication. On 27 January 2020 all the plants growing in the gravel area illustrated in Fig. 18 were removed and the area covered with fresh gravel, a further illustration of the short-term changes affecting the street flora.

Copyright retained by author(s). Published by BSBI under the terms of the Creative Commons Attribution 4.0 International Public License.

ISSN: $2632-4970$

https://doi.org/10.33928/bib.2020.02.001 